\title{
Article \\ Energy Transition on Sifnos: An Approach to Economic and Social Transition and Development
}

\author{
Dimtris A. Katsaprakakis ${ }^{1, *(D)}$, Eirini Dakanali ${ }^{1}$, Apostolos Dimopoulos ${ }^{2}$ and Yiannis Gyllis ${ }^{2}$ \\ 1 Power Plant Synthesis Laboratory, Department of Mechanical Engineering, \\ Hellenic Mediterranean University, 71410 Heraklion, Greece; dakanali@hmu.gr \\ 2 Sifnos Energy Community, 84003 Apollonia, Greece; apostolos.sifnos@gmail.com (A.D.); \\ igyllis@hotmail.com (Y.G.) \\ * Correspondence: dkatsap@hmu.gr; Tel.: +30-2810-379220
}

check for

updates

Citation: Katsaprakakis, D.A.;

Dakanali, E.; Dimopoulos, A.; Gyllis, Y. Energy Transition on Sifnos: An Approach to Economic and Social Transition and Development. Appl. Sci. 2022, 12, 2680. https://doi.org/ 10.3390/app12052680

Academic Editors: Petros

Chasapogiannis, Vasilis Riziotis and George Caralis

Received: 13 January 2022

Accepted: 28 February 2022

Published: 4 March 2022

Publisher's Note: MDPI stays neutral with regard to jurisdictional claims in published maps and institutional affiliations.

Copyright: (C) 2022 by the authors. Licensee MDPI, Basel, Switzerland. This article is an open access article distributed under the terms and conditions of the Creative Commons Attribution (CC BY) license (https:// creativecommons.org/licenses/by/ $4.0 /)$.
Abstract: This article aims to present the potential of energy transition in insular systems for social and economic transition and development, when planned and implemented appropriately, with the active involvement of local communities. To this end, the example of Sifnos Energy Community is examined and presented as a pilot case. It proves that energy transition, apart from its obvious energy conservation and climate necessity, can provide a strong contribution to the development of remote areas and the remedying of crucial issues, especially in insular communities, such as unemployment, low standards of living, isolation and energy supply security. Energy transition on Sifnos has been undertaken by the Sifnos Energy Community (SEC), with the target to achieve $100 \%$ energy independency through effective and rational projects. The major project is a centralized hybrid power plant consisting of a wind park and a pumped hydro storage system. It was designed to fully cover the current electricity demand and the anticipated forthcoming load due to the overall transition to e-mobility for the transportation sector on the island. Through the exploitation of the excess electricity production with the production of potable water and hydrogen, energy transition can facilitate the development of new professional activities on the island and reduce the local economy's dependence on tourism. Additionally, a daily link to the neighboring larger Cyclades islands can be established with a hydrogen powered-passenger vessel, ensuring the secure and cheap overseas transportation connection of Sifnos throughout the whole year. The overall energy transition process is executed with the active involvement of the Sifnos citizens, ensuring wide public acceptance and the minimization of the projects' impacts on the natural and human environment. At the same time, the anticipated benefits for the insular communities are maximized, highlighting the energy transition process on Sifnos as a new sustainable development pattern. For all this effort and the already achieved results, Sifnos has been declared as one of the six pilot islands of the European Community's initiative "Clean Energy for EU Islands".

Keywords: energy transition; hybrid power plants; energy communities; pumped hydro storage; energy independency democracy

\section{Introduction}

\subsection{The Sifnos Island}

Sifnos is a small, so far non-interconnected island, either with the mainland system or with a neighboring insular grid, located in the western part of the Cyclades complex in the Aegean Sea, Greece (Figure 1), with a population of 2625 and a total area of $73.9 \mathrm{~km}^{2}$ [1].

The economy on Sifnos is based on tourism. As shown in Figure 2, more than $75 \%$ of the human resources on the island are occupied in jobs related to tourism [2,3] (apart from human health, education and administration). 


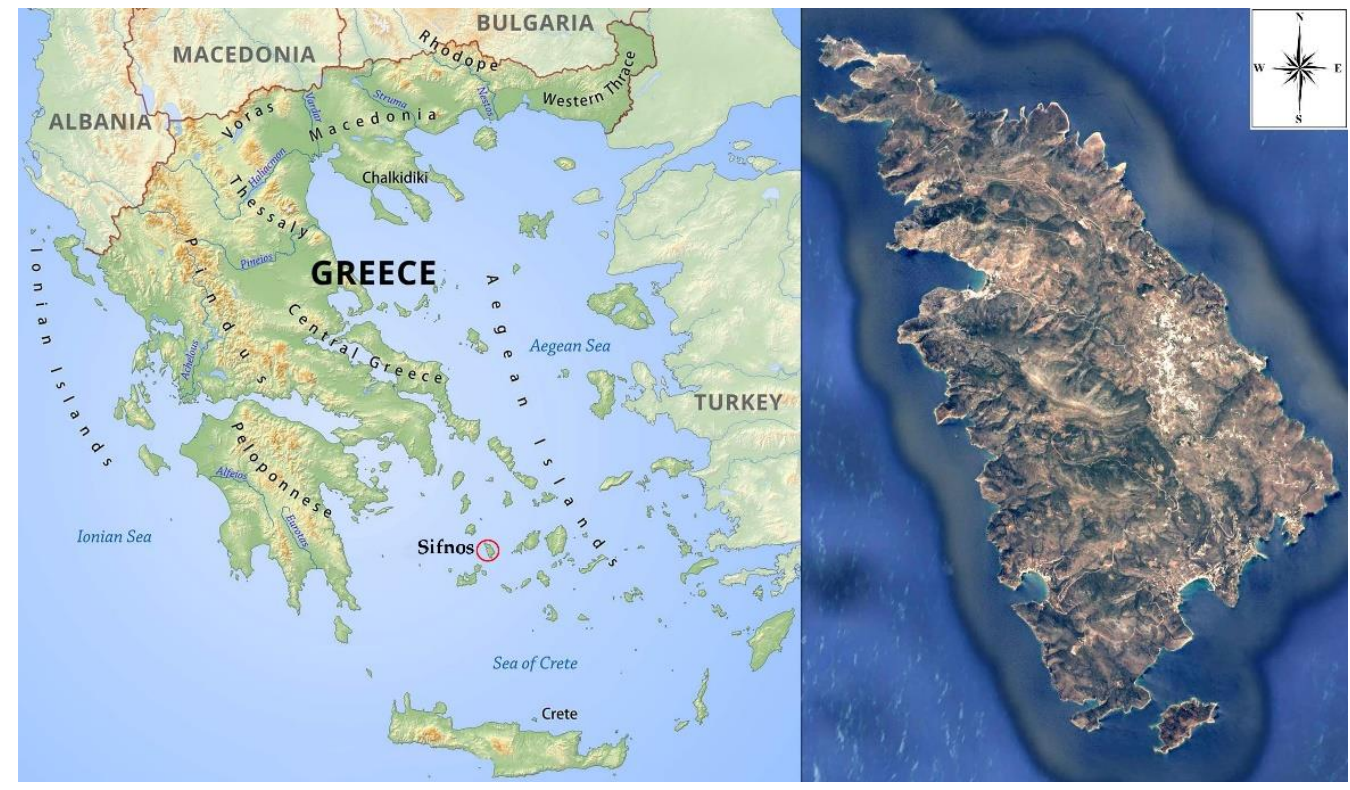

Figure 1. The map of Sifnos and its geographical location in Greece.

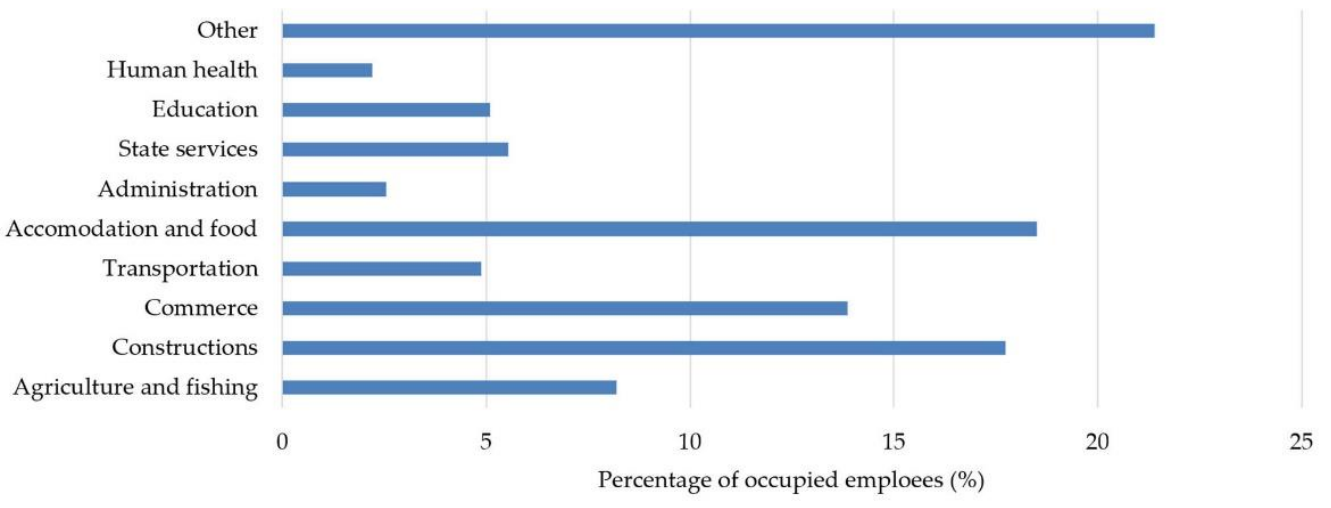

Figure 2. Percentage graph of the occupied employees on Sifnos per occupation category.

The energy consumption on the island is found in:

- The coverage of the energy needs in the building sector (residential, commercial and administrative facilities), which traditionally refer to heating and cooling, lighting and mechanical power in motors. These energy needs are almost exclusively covered by electricity, except a small contribution of diesel oil and solar collectors for heat production $[4,5]$.

- The municipal public lighting and the water pumping, desalination and distribution facilities, covered exclusively by electricity.

- The transportation on the island, covered exclusively by liquid fossil fuels (diesel oil and gasoline).

- The overseas transportation from and to the island, covered by liquid fossil fuels (heavy fuel and diesel oil).

The final energy consumption levels are analyzed in Table 1 [6]. These figures were derived from the Clean Energy Transition Agenda (CETA) of Sifnos. The $\mathrm{CO}_{2}$ emissions were calculated following the factors given for each different energy source in the Greek Directive for Buildings Energy Performance Upgrade [7]. 
Table 1. Analysis of annual energy consumptions on Sifnos.

\begin{tabular}{|c|c|c|c|c|}
\hline & $\begin{array}{l}\text { Annual Final Energy } \\
\text { Consumption (MWh) }\end{array}$ & $\begin{array}{c}\text { Percentage } \\
\text { Contribution (\%) }\end{array}$ & $\begin{array}{l}\text { Annual Primary Energy } \\
\text { Consumption (MWh) }\end{array}$ & $\begin{array}{c}\mathrm{CO}_{2} \text { Annual } \\
\text { Emissions (tn) }\end{array}$ \\
\hline \multicolumn{5}{|c|}{ Electricity consumption } \\
\hline Municipal and public buildings & 1571 & 9.0 & 4557 & 3558 \\
\hline Residential sector & 4365 & 25.0 & 12,659 & 9883 \\
\hline Primary sector & 175 & 1.0 & 506 & 395 \\
\hline Industry & 0 & 0.0 & 0 & 0 \\
\hline Tertiary sector & 10,477 & 60.0 & 30,382 & 23,720 \\
\hline Municipal facilities & 873 & 5.0 & 2532 & 1977 \\
\hline Total & 17,461 & 100.0 & 50,637 & 39,533 \\
\hline \multicolumn{5}{|c|}{ Transportations on the island } \\
\hline LPG & 0 & 0.0 & 0 & 0 \\
\hline Diesel oil & 8813 & 51.0 & 9695 & 2559 \\
\hline Gasoline & 8468 & 49.0 & 9314 & 2329 \\
\hline Total & 17,281 & 100.0 & 19,009 & 4888 \\
\hline \multicolumn{5}{|c|}{ Transportations from and to the island } \\
\hline Heavy fuel & 0 & 0.0 & 0 & 0 \\
\hline Diesel oil & 529,733 & 100.0 & 582,706 & 153,834 \\
\hline Kerosene (aviation) & 0 & 0.0 & 0 & 0 \\
\hline Total & 529,733 & 100.0 & 582,706 & 153,834 \\
\hline \multicolumn{5}{|c|}{ Heat } \\
\hline Oil heaters & 2800 & 81.7 & 3.080 & 813 \\
\hline Wood/biomass & 0 & 0.0 & 0 & 0 \\
\hline LPG & 0 & 0.0 & 0 & 0 \\
\hline Solar collectors & 628 & 18.3 & 0 & 0 \\
\hline Total & 3428 & 100.0 & 3.080 & 813 \\
\hline Totals & 567.903 & & 655.432 & 199.068 \\
\hline
\end{tabular}

In brief, the following conclusions may be drawn by observing these facts:

- Electricity and diesel oil are the main energy sources on the island.

- Apart from a low heat production from solar collectors for hot water domestic use, there is not any other use of renewable energy sources (RES) for heat production.

- Diesel oil and gasoline are the exclusive energy sources used in the onshore transportation sector.

The tertiary sector, which on Sifnos actually means tourist facilities, exhibits the highest percentage share $(60 \%)$ regarding electricity consumption. It is also clarified that the last part of Table 1 presents the energy sources used for heat production apart from electricity, which are obviously consumed for both indoor space heating and hot water production, accounted for in the electricity consumption presented in the first part of Table 1.

The data presented in Table 1 are also graphically summarized in Figure 3. Specifically, the annual percentage contribution of the final energy uses is depicted in Figure 3a [6], with the transportation sector from and to the island constituting the dominant energy use. In Figure 3b, the percentage contribution of different sectors to the annual electricity consumption is presented. 


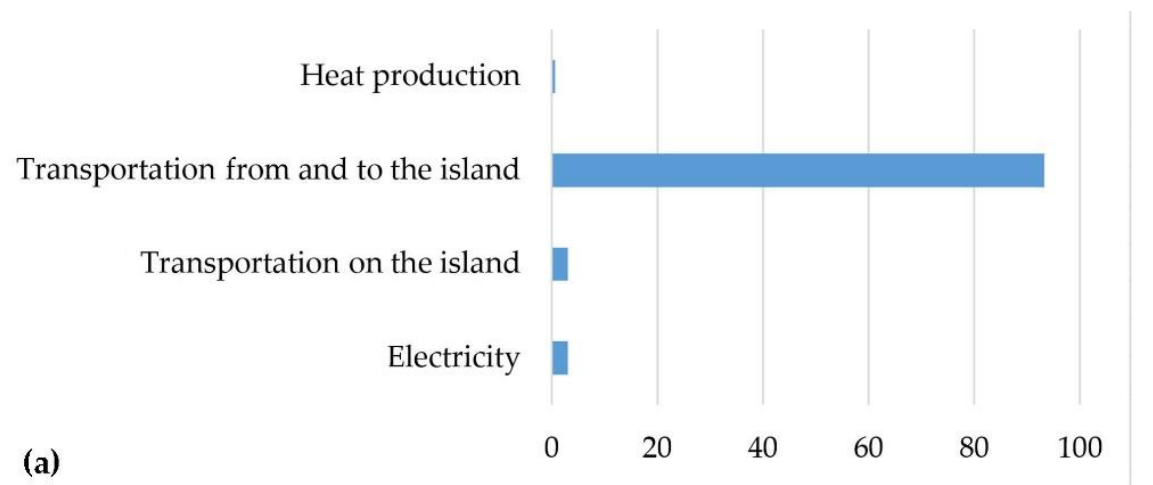

Annual contribution to the total energy consumption (\%)

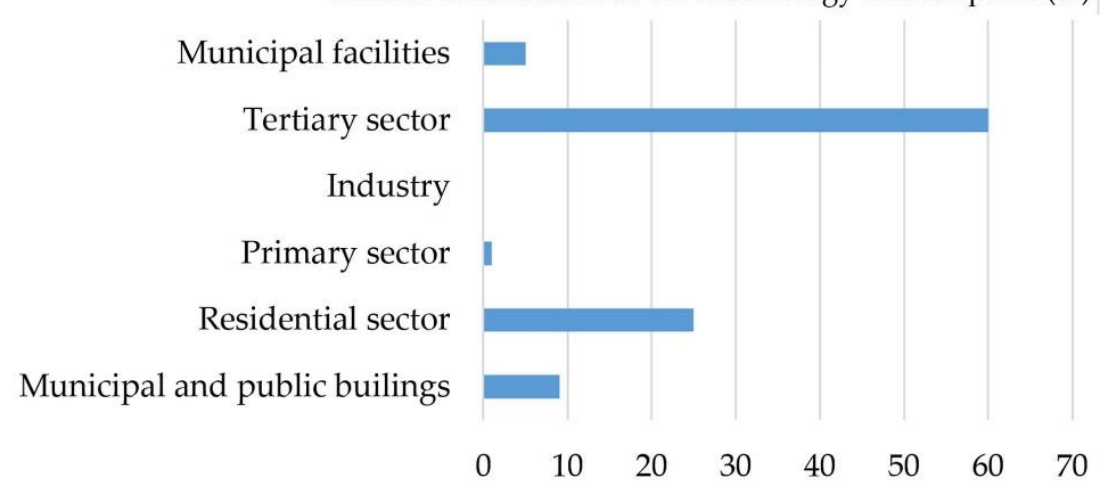

(b)

Annual contribution to the electricity consumption (\%)

Figure 3. Annual contribution of final energy uses to the total energy consumption on Sifnos (a) and annual contribution of different sectors to the electricity consumption in the island (b).

Regarding the onshore energy consumption, Sifnos almost totally depends on imported fossil fuels for onshore transportation and electricity production. Electricity production is mainly based on the island's autonomous power plant (APP), equipped with nine diesel generators of 1.1 MW nominal power each. All of these generators are powered by diesel oil, with an average procurement price above EUR 950/kL. The total levelized electricity production cost on Sifnos was configured at EUR 344.07/MWh in 2015 [8]. This total cost was formulated by the variable cost, calculated at EUR 222.62/MWh, and the fixed cost, calculated at EUR 121.45/MWh [8]. At the same time, the levelized electricity production cost in the mainland electricity system in Greece was formulated at EUR 58.099/MWh on average in 2020 [9]. This comparison reveals the extremely high production cost on Sifnos, which is due to the consumption of expensive diesel oil and the necessity for spinning reserve maintenance, which requires the diesel generators' operation with partial loads, leading to reduced efficiency [10].

Apart from the aforementioned thermal APP, power is supplementarily produced on Sifnos by means of $335 \mathrm{~kW}$ of small, decentralized photovoltaic stations and a small wind park of two wind turbines with a total nominal power of $1.26 \mathrm{MW}$, installed and connected to the local grid in 2019.

The strong dependence of the economic activity on Sifnos on tourism inevitably leads to annual power demand fluctuation, presented in Figure 4 for 2015. As seen in this figure, the power demand is almost three times higher in summer (tourist season) than in winter, revealing the power demand's seasonality on the island. The annual peak demand was configured at 5.90 MW in August. The peak demand during the winter period did not exceed 2.5 MW, excluding the Easter period, during which a sudden and short demand increase close to $4 \mathrm{MW}$ is observed. The minimum demand is found in the winter months at slightly lower than 1.0 MW. The annual electricity consumption in 2015 was 17,461 MWh. 


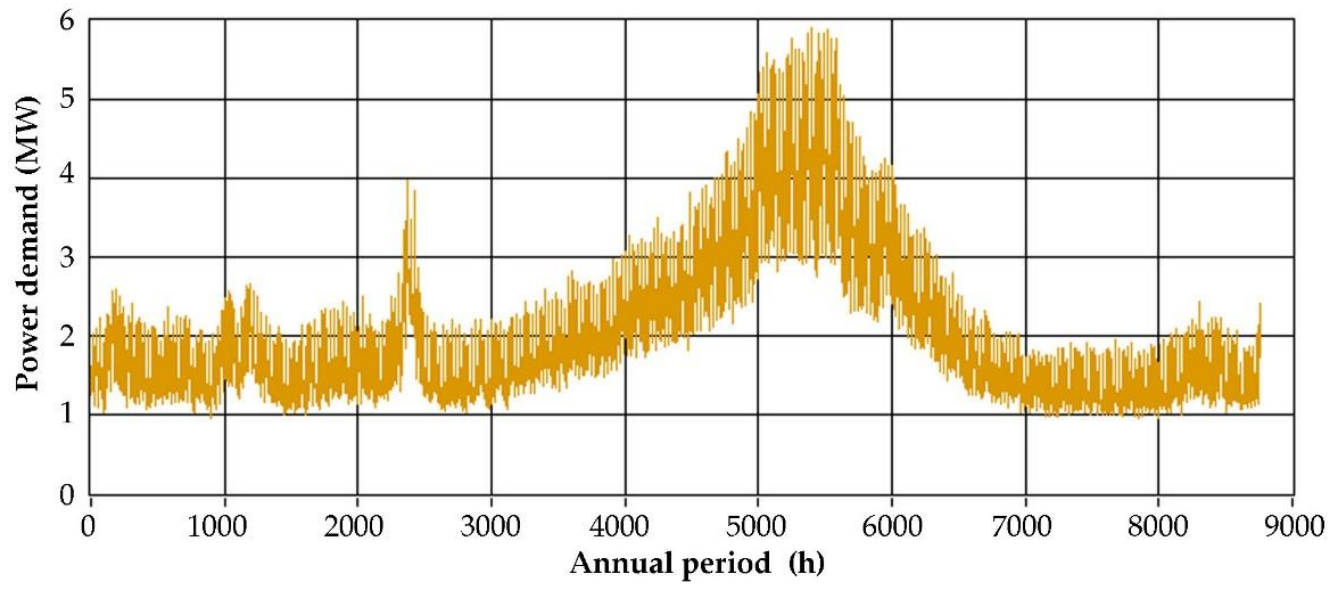

Figure 4. Annual power demand fluctuation on Sifnos in 2015.

Following the computational simulation of the annual operation of the autonomous electrical system on Sifnos for the year 2021, executed on the basis of an annual time series with hourly averaged values, the annual production contributions of all the involved power generators are summarized in Table 2.

Table 2. Analysis of the annual electricity production on Sifnos in 2021.

\begin{tabular}{|c|c|c|c|c|c|}
\hline Unit/Process & $\begin{array}{l}\text { Annual } \\
\text { Electricity } \\
\text { Production } \\
\text { (MWh) }\end{array}$ & $\begin{array}{c}\text { Annual Average } \\
\text { Total Efficiency } \\
(\%)\end{array}$ & $\begin{array}{l}\text { Annual Average } \\
\text { Levelized Variable } \\
\text { Production Cost } \\
\text { (EUR/kWh) }\end{array}$ & $\begin{array}{c}\text { Diesel Oil } \\
\text { Annual } \\
\text { Consumption } \\
(\mathbf{k L})\end{array}$ & $\begin{array}{c}\text { Diesel Oil } \\
\text { Annual } \\
\text { Procurement } \\
\text { Cost (MEUR) }\end{array}$ \\
\hline Thermal generator 1 & 6097.63 & 40.51 & 0.2416 & 1540.753 & 1.473 \\
\hline Thermal generator 2 & 5459.16 & 40.30 & 0.2428 & 1386.532 & 1.326 \\
\hline Thermal generator 3 & 3543.60 & 40.16 & 0.2437 & 903.162 & 0.863 \\
\hline Thermal generator 4 & 1583.80 & 40.12 & 0.2439 & 404.049 & 0.386 \\
\hline Thermal generator 5 & 482.65 & 40.10 & 0.2440 & 123.184 & 0.118 \\
\hline Thermal generator 6 & 99.20 & 40.09 & 0.2441 & 25.327 & 0.024 \\
\hline Thermal generator 7 & 9.60 & 40.09 & 0.2441 & 2.451 & 0.002 \\
\hline Thermal generator 8 & 0.00 & - & - & 0 & 0 \\
\hline Wind park & 1339.52 & - & 0.0900 & - & - \\
\hline Photovoltaic stations & 242.85 & - & 0.2500 & - & - \\
\hline Start-up process & - & - & - & 2.988 & 0.003 \\
\hline Total & $18,858.01$ & * 40.32 & 0.2321 & 4388.456 & 4.195 \\
\hline
\end{tabular}

*: it refers to the total, annual average efficiency of the thermal generators.

The annual power demand has been adapted, assuming annual increase percentages in the range of $1-2 \%$. The annual electricity demand is estimated at $18,858 \mathrm{MWh}$. In total, 1582.4 MWh, namely $8.4 \%$ of this annual consumption, is covered by the already existing electricity production plants from RES. Just for comparison reasons, in the whole country, the RES contribution to the electricity demand coverage in 2021 was close to $49 \%$ [11]. It is underlined that in Table 2, only the variable production cost is presented, as calculated from the computational simulation process. As seen, the calculated figure is very close to the official one supplied by HEDNO.

Finally, a forthcoming critical evolution regarding the insular grid on Sifnos is its planned interconnection with the mainland grid. This will create new standards, new perspectives and new opportunities as far as energy transition on the island is concerned, as will be shown in Section 4 . 


\subsection{Prior Literature Regarding Energy Transition in Insular Systems}

Energy transition refers to the process of moving towards the replacement of the currently used fossil fuels for energy production with RES, as well as the introduction of new energy systems with improved operation efficiency and low primary energy consumption, described with the term "rational use of energy" (RUE) [12,13]. The necessity and the essential guidelines of energy transition were set by the European Commission in the Directives (EU) 2018/2001 [14] and (EU) 2018/844 [15].

In the technical and scientific literature, energy transition, particularly for islands, constitutes a popular and widely studied topic. The relevant articles can be distinguished into two main categories:

- Articles studying the technical aspects of power production systems, including the layout, the operation algorithm, the introduction of new technologies or the combination of systems, etc.

- Articles studying the social, environmental and developmental perspectives of energy transition.

Energy transition on islands is mainly approached using electricity production technologies from RES, supported by storage plants, formulating in this way the so-called "hybrid power plants" (HPP). For large islands, with a power demand higher than $5 \mathrm{MW}$, the optimum storage technology has by far been proved to be the pumped hydro storage (PHS) systems [14-19], due to their large storage capacity, their considerably long autonomy operation period and the low specific cost of set up, which, under favorable land morphology and appropriate placement, can be as low as EUR 30/kWh of storage capacity [10]. PHS systems can also contribute to the regulation of the electrical grid frequency, through both the fast and flexible operation of hydro turbines and the management of the pump loads [20]. Thus far, there are two integrated and operating wind parks-the PHS systems in the islands of El Hierro, Canary Islands, Spain [21,22] and Ikaria, Eastern Aegean Sea, Greece [23].

For smaller islands, with peak demand lower than $5 \mathrm{MW}$, normally the high infrastructure set-up costs of PHS systems cannot be compensated by the relatively low electricity demand, although there can be cases with favorable land morphology and high existing electricity production specific cost where PHS systems can be feasible [24]. However, such cases should be considered as exceptions. Usually, small hybrid power plants are supported by electrochemical storage devices. The scientific literature on such small systems usually deals with their technical and economic feasibility, under alternative operation algorithms, involved technologies and insular conditions [25-27]. The essential feature of these technologies is their considerably high set-up cost, caused mainly by the high procurement cost of batteries (EUR 200-500/ $\mathrm{kWh}$, depending on the storage technology) and their low lifetime period, which further increases the project's set-up cost due to the required regular replacements [28-30]. For this reason, such systems are usually proposed with a small number of storage modules and, subsequently, low storage capacity. Aiming to overcome this drawback, sophisticated solutions with additional storage alternatives are often examined, with the most popular being hydrogen production via electrolysis units [31-33]. Finally, in case of islands with extensive agricultural and stock farming activities, the introduction of biomass-based systems has been proposed [34]. On Réunion Island, for example, the available biomass sources can cover more than $50 \%$ of the annual electricity demand $[35,36]$.

The second type of article deals with the environmental, social and economic extensions of energy transition, such as the public acceptance of energy transition projects and the maximization of their contribution to the social and economic growth of insular communities. Both of these subjects can be approached by following the three main pillars of research:

- The adequate and appropriate awareness of the local communities regarding the energy transition process, its necessity and objectives, the risks undertaken and the 
potentially required projects and, finally, the perspectives and the anticipated benefits for the local communities. All of these can be achieved through appropriate capacity building campaigns [37,38].

- The minimization or even the elimination of any potential impacts from the implementation of the required energy transition projects on the natural environment and human activities. These can be achieved with the selection of optimum technologies, their appropriate sizing [39-41] and the selection of the installation sites following a predefined spatial planning, which will take into account, apart from the availability of RES potential, all existing restrictions and sensibilities of environmental, cultural, historical and economic interest.

- The third pillar constitutes an essential prerequisite for the achievement of the aforementioned targets. This is the active involvement of the local community in the design, the implementation and the operation and management of the energy transition projects. The most effective way for citizens and local stakeholders to be involved in these is through energy cooperatives or communities [10,42].

From the literature search presented here, the absence of articles which examine the energy transition holistically as a pillar for social and economic development in insular, isolated communities is revealed. This work, by presenting the overall effort is Sifnos, aims to introduce in the scientific literature an integrated pilot case for how rational and effective energy transition can be exploited in order to achieve the sustainable and fair development of entire insular communities, without inequalities or discrimination. This is achieved by introducing for the first time an integrated cluster of projects which operate in a combined mode, with a hybrid power plant being the basic component. New operation algorithms have been also introduced.

\subsection{Energy Transition on Sifnos - The Sifnos Energy Community}

The idea and the necessity for energy transition on Sifnos was transferred to the islanders directly through their contacts with energy cooperatives from other countries, given the following facts on Sifnos:

- The strong dependence of the island on imported energy sources.

- The high electricity production cost [10].

- The fact that the final electricity procurement price for the final consumers is equal everywhere in Greece, regardless of the differences in the levelized energy production cost between the mainland and the insular grids. This means that the mainland consumers subsidize the low electricity procurement price in the insular, autonomous grids in Greece by paying a higher price than the levelized production cost in the interconnected mainland grid.

- The forthcoming liberalization of the electricity wholesale market, which will probably overturn the previously described status regarding the equal electricity price in Greece [43,44].

- The high investment interest from private investors for the development of electricity production plants from RES on the Greek islands, revealing, on the one hand, the high available wind and solar potential and threatening, on the other hand, to modify the insular environments in decentralized industrial zones through the development of disproportional large projects in these small and sensitive natural ecosystems [45].

- The European Commission directives and what happens in Europe with the foundation and the activation of hundreds of Energy Cooperatives.

Given the aforementioned facts, some few tens of Sifnos residents founded, in 2013, the Sifnos Island Cooperative (SIC) [46], aiming to drive a rational, fair and effective energy transition for their island, with the optimum possible benefits for their community. At that time, the SIC was the first cooperative scheme among insular Greece communities. Today, the SIC has transformed into the Sifnos Energy Community (SEC). More than 150 Sifnos families, out of the 800 in total, together with the Municipality of Sifnos and a number of 
members outside Sifnos, participate in the SEC, making it the largest in Greece with regard to its size per capita.

To date, the SEC has been active in the following initiatives and projects:

- Capacity building of the local insular community based on the concept of energy transition and the objectives of the SEC.

- The design, the siting, the sizing and the submission for licensing of a hybrid power plant, consisting of a wind park and a PHS system, with the target to undertake $100 \%$ of the current and the future electricity consumption in the island, accounting also for the transition to e-mobility and additional expected electricity loads $[47,48]$. The project was designed and licensed despite the fact that the electricity selling price from the HPP to the grid still remains unknown, due to revisions of the relevant legislation.

- In November 2018, the SIC joined the European Commission network of the "Clean Energy for EU Islands" initiative and was declared as one of the six pilot islands of the European Union. As a pilot island, the SIC undertook and fulfilled the obligation of the design and the writing of the Clean Energy Transition Agenda (CETA) [6].

The distinction of Sifnos as one of the six pilot islands by the European Commission constitutes a reward for the efforts of the SIC since 2013. At the same time, it reveals the innovation and the challenges of the overall venture, while it designates the route towards energy transition on Sifnos as a pilot for the whole of Europe. Indeed, the SEC's initiative, particularly through the design and the development of the hybrid power plant, has the following innovative features at the global level:

- It is the first project at the global level involving a hybrid power plant based on the combined operation of a wind park and PHS system operating with seawater.

- It is the first project at the global level with a sizing which aims at $100 \%$ electricity demand coverage in an autonomous, non-interconnected insular electrical system.

- It is the first project at the global level which aims at achieving $100 \%$ coverage of the needs of all final energy forms in an autonomous, non-interconnected island, implemented by a local energy cooperative scheme.

Given the above facts, the successful integration of the SEC's targets and objectives constitutes a pan-European target, and will act as a pilot for all European Islands.

\section{Methodology}

This article aimed to present the potential of energy transition in insular systems for social and economic transition and development, once planned and implemented appropriately, with the active involvement of local communities. To this end, the example of the Sifnos Energy Community was examined and presented as a pilot case.

The article firstly presented the current energy consumption on the island, together with social and economic features which outline the weak points and the clear growth trend. Energy transition on Sifnos was designed on the basis of a major project, a hybrid power plant consisting of a wind park and a PHS system, thoroughly presented in Section 2, regarding its essential aspects: planning, operation algorithm and sizing. The sizing was executed according to a single and clear criterion: the ability of the hybrid power plant to fully undertake the electricity consumption on Sifnos. The goal was $100 \%$ real-time and annual electricity coverage from the hybrid power plant. No other dimensioning criteria were introduced. Once the operation algorithm was computationally simulated, the application was executed iteratively, by alternating the wind parks' power and the storage reservoir capacity, until the aforementioned target was met, with the minimum possible set-up cost. The introduced hybrid power plant was finally evaluated with the use of the Wind Farm R5 software versus its potential impacts on the natural environment and existing human activities aiming at their elimination, so as to ensure public acceptance and accelerate the licensing process period.

This article also made extensive reference to the development perspectives on Sifnos, arising from the exploitation of the electricity production surplus from the hybrid plant. The 
excess electricity can support the full transition to e-mobility for the transportation on the island, the increase in potable water production through desalination plants and hydrogen production to power a daily voyage which will address insular isolation, especially during winter. The annual operation of the hydrogen production and storage plant was also computationally simulated, and it was designed to cover the annually required amount of hydrogen for the execution of the voyage on a daily basis. Through this analysis, the article proves the strong developmental perspectives created for the insular community via energy transition.

Finally, the article was integrated with the analysis and discussions of two major uncertainties, with regard to the implementation of the hybrid plant: the forthcoming electrical interconnection of Sifnos with the mainland grid and the produced electricity selling price, which has not been configured yet. By accomplishing an essential economic analysis of the hybrid plant's investment and by considering several failure events that occurred in similar interconnected island cases, this article aimed to predict and set any potential risks and thresholds (e.g., for the electricity selling price), in order to ensure the feasibility and the economic viability of the proposed hybrid plant.

The present article aspired to constitute a reference document on the way that energy transition can be transformed into a pillar for social and economic transition and development for insular communities.

\section{The Hybrid Power Plant of Sifnos}

\subsection{Essential Features}

The hybrid power plant on Sifnos was designed with the essential objective to fully cover the electricity consumption on the island, as is expected to be formulated in the future with the achievement of energy transition for all final energy needs in all sectors (residential, tertiary, primary, municipal facilities, and transportation on the island). Aiming at the construction of a project with the minimum possible set-up and operation cost, adequate storage capacity and technical operational features appropriate to support the insular grid's requirements regarding stability, dynamic security and power quality, a wind park and a PHS system were selected.

PHS was selected as the optimum storage technology, given the fact that it is the only mature technology with which storage capacities in the range of hundreds of MWhs can be achieved [49-51]. Additionally, the PHS system, under proper maintenance, exhibits a life period of multiple decades, unlike the short life period of electrochemical storage devices [49]. Given the lack of adequate potable water for the needs of the PHS, the use of seawater was selected as the only available alternative [52-54].

A wind park was selected instead of a photovoltaic park, given the capacity factors of wind parks in Greek islands being almost double those of photovoltaics. Additionally, the large storage capacity of the PHS system ensures the long autonomy operation period of the storage plant, without intermediate storage from the RES plant (e.g., in case of a long period with low wind), making the parallel production of an alternative RES technology unnecessary (e.g., photovoltaics).

The hybrid power plant's sizing was established through the computational simulation of its annual operation, executed with a relevant application designed and developed by the project's scientific team [10]. The hybrid plant's operation algorithm is presented in the following section.

\subsection{The Hybrid Power Plant's Operation Algorithm}

The operation algorithm of the hybrid power plant is presented below.

1. The calculation data of the overall process are the power production $P_{\text {RES }}$ from the hybrid power plant's RES unit (namely the wind park) and the power demand $\mathrm{P}_{\mathrm{d}}$. These data are introduced with the annual time series of hourly average values. For every time step, the following calculations are executed. 
2. In order to ensure the dynamic security and the stability of the insular grid, the wind power penetration $P_{\text {RESp }}$ for the power demand direct coverage is limited up to a maximum percentage a, equal to $40 \%$ over the power demand. This means that the wind park's direct penetration $P_{\text {RESp }}$ will be equal to:

$$
\begin{aligned}
& \text { i. if } P_{R E S}>a \cdot P_{d} \text {, then } P_{R E S p}=a \cdot P_{d} \\
& \text { ii. if } P_{R E S} \leq a \cdot P_{d} \text {, then } P_{R E S p}=P_{R E S} .
\end{aligned}
$$

3. After the wind power direct penetration, the remaining power demand $P_{\text {drem }}$ will be:

$$
\mathrm{P}_{\text {drem }}=\mathrm{P}_{\mathrm{d}}-\mathrm{P}_{\mathrm{RESp}} \text {. }
$$

4. The power available for storage $\mathrm{P}_{\text {RESav }}$ will be:

$$
P_{\text {RESav }}=P_{\text {RES }}-P_{\text {RESp }}
$$

5. The water volume $V_{P}$ required to be pumped in the PHS upper reservoir, so that the available power $P_{\text {RESav }}$ for a time step of duration $t$ can be stored, is given by the following relationship (where $\gamma$ is the water specific weight, $\mathrm{H}_{P}$ is the total pumping head and $\eta_{P}$ is the pumps' average efficiency) [55]:

$$
\mathrm{V}_{\mathrm{p}}=\eta_{\mathrm{p}} \cdot \mathrm{P}_{\mathrm{RESav}} \cdot \mathrm{t} / \gamma \cdot \mathrm{H}_{\mathrm{P}}
$$

6. The water volume $\mathrm{V}_{\mathrm{T}}$ required to be supplied from the upper reservoir, so that the remaining power demand $\mathrm{P}_{\mathrm{d}}-\mathrm{P}_{\mathrm{RESp}}$ for a time step of duration $\mathrm{t}$ can be covered by the hydro turbines, is given by the following relationship (where $\mathrm{H}_{\mathrm{h}}$ is the total water falling head and $\eta_{\mathrm{h}}$ is the hydro turbines' average efficiency) [55]:

$$
\mathrm{V}_{\mathrm{T}}=\left(\mathrm{P}_{\mathrm{d}}-\mathrm{P}_{\mathrm{RESp}}\right) \cdot \mathrm{t} / \eta_{\mathrm{h}} \cdot \gamma \cdot \mathrm{H}_{\mathrm{h}}
$$

7. The remaining water volume $\mathrm{V}_{\mathrm{st}}(\mathrm{j})$ in the PHS upper reservoir at the end of the current time calculation step $\mathrm{j}$ will be:

$$
V_{s t}(j)=V_{s t}(j-1)+V_{p}-V_{h}
$$

8. If the remaining water volume in the PHS upper reservoir exceeds the reservoir's maximum capacity $V_{\max }$, then:

i. If $V_{\text {st }}(j)>V_{\text {max }}$, then (where $P_{\text {st }}$ is the power storage, $P_{\text {sur }}$ is the wind power production surplus, and $\mathrm{P}_{\mathrm{h}}$ and $\mathrm{P}_{\text {th }}$ represent the electricity power production from the hydro turbines and the thermal generators, respectively) [55]:

$$
\begin{gathered}
P_{h}=P_{d}-P_{\text {RESp }} \\
P_{\text {th }}=0 \\
P_{\text {st }}=\gamma \cdot H_{p} \cdot\left(V_{\text {max }}-V_{\text {st }}(j)\right) /\left(t \cdot \eta_{p}\right) \\
P_{\text {sur }}=P_{\text {RESav }}-P_{\text {st }} \\
V_{\text {st }}(j)=V_{\text {max }} .
\end{gathered}
$$

ii. If $\mathrm{V}_{\mathrm{st}}(\mathrm{j}) \leq \mathrm{V}_{\max }$, then the remaining water volume in the upper reservoir is checked as to whether it is lower or not than the minimum water volume which is always contained in the reservoir, due to constructive limitations: 
a. if $\mathrm{V}_{\mathrm{st}}(\mathrm{j})<\mathrm{V}_{\mathrm{min}}$, then the water volume contained in the upper reservoir is not enough to undertake the remaining power demand coverage. In this case [55]:

$$
\begin{gathered}
P_{h}=\eta_{h} \cdot \gamma \cdot H_{h} \cdot\left(V_{s t}(j)-V_{\text {min }}\right) / t \\
P_{\text {th }}=P_{d}-P_{\text {RESp }}-P_{h} \\
P_{\text {st }}=P_{\text {RESav }} \\
P_{\text {sur }}=0 \\
V_{\text {st }}(j)=V_{\text {min }} .
\end{gathered}
$$

b. if $V_{s t}(j) \geq V_{\text {min }}$, then the remaining power demand can be covered by the hydro turbines, hence, the power produced by the hydro turbines is calculated by using Equation (8) and the power produced by the thermal generators is null (Equation (9)). Additionally, the power storage is given by Equation (15) and the power production surplus from the wind park is null (Equation (16)). Finally, the remaining water volume in the upper tank is given by the Equation (7).

The above presented algorithm was executed for a new power demand time series developed to include both the current power demand and the anticipated additional demand due to the transition to e-mobility. It is analyzed in the following section.

\subsection{Computational Simulation Data}

For the computational simulation of the hybrid power plant's annual operation, a new power demand annual time series was developed, as the aggregate of the current power demand and the electrical vehicles (EVs) charging load, anticipated due to the full transition to e-mobility. For the estimation of the latter, according to the CETA [6], the annual existing final energy consumption for the transportation on the island was calculated at 17,281 MWh. Considering the lower calorific value of diesel oil and gasoline at 10.0 and $8.9 \mathrm{kWh} / \mathrm{L}$, respectively [56], an average fuel-specific consumption in conventional vehicles of $7.5 \mathrm{~L} / 100 \mathrm{~km}$ and an average electricity-specific consumption of a corresponding electrical vehicle of $20 \mathrm{kWh} / 100 \mathrm{~km}$ [57], the total electricity consumption for the full transition to e-mobility for the onshore transportations was calculated at $1500 \mathrm{MWh}$.

The new power demand for charging EVs was developed by introducing a daily charging profile, shown in Figure 5, based on existing literature approaches [58]. Different charging load daily profiles were introduced for EVs charging at home, at work and at public charging stations. The annual EV charging load time series was developed by simply replicating the daily profiles for the whole year.

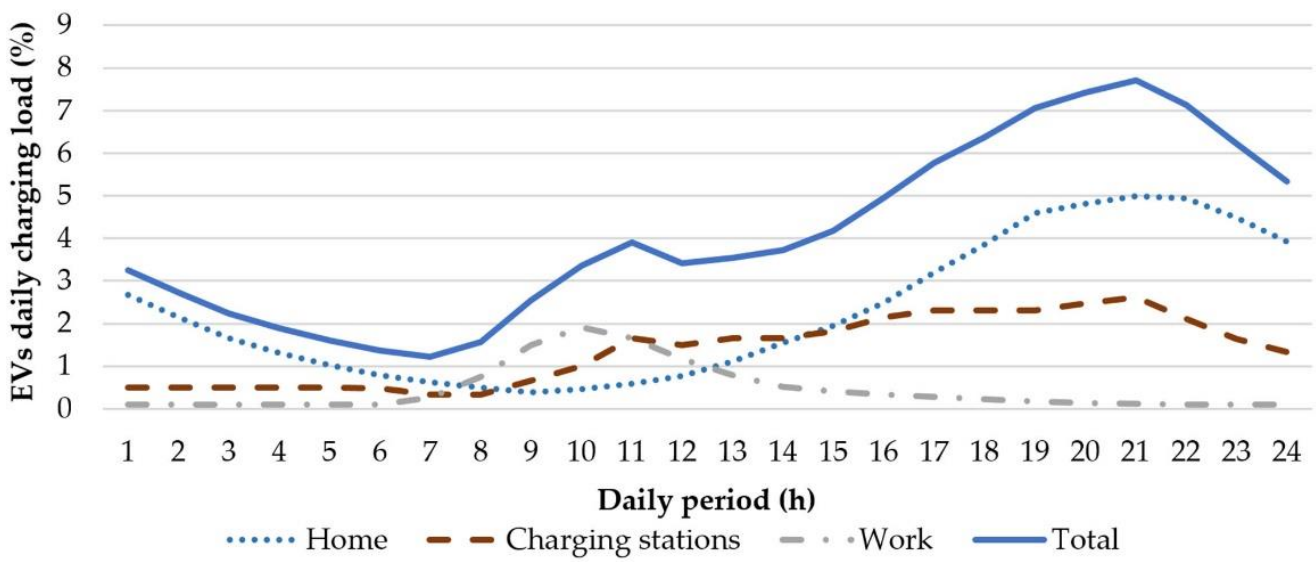

Figure 5. Daily charging load profiles for the EVs. 
The newly developed annual power demand time series is presented in Figure 6. The annual peak demand and the annual electricity consumption are calculated as being equal to 6.71 and 20,357 MWh, respectively.

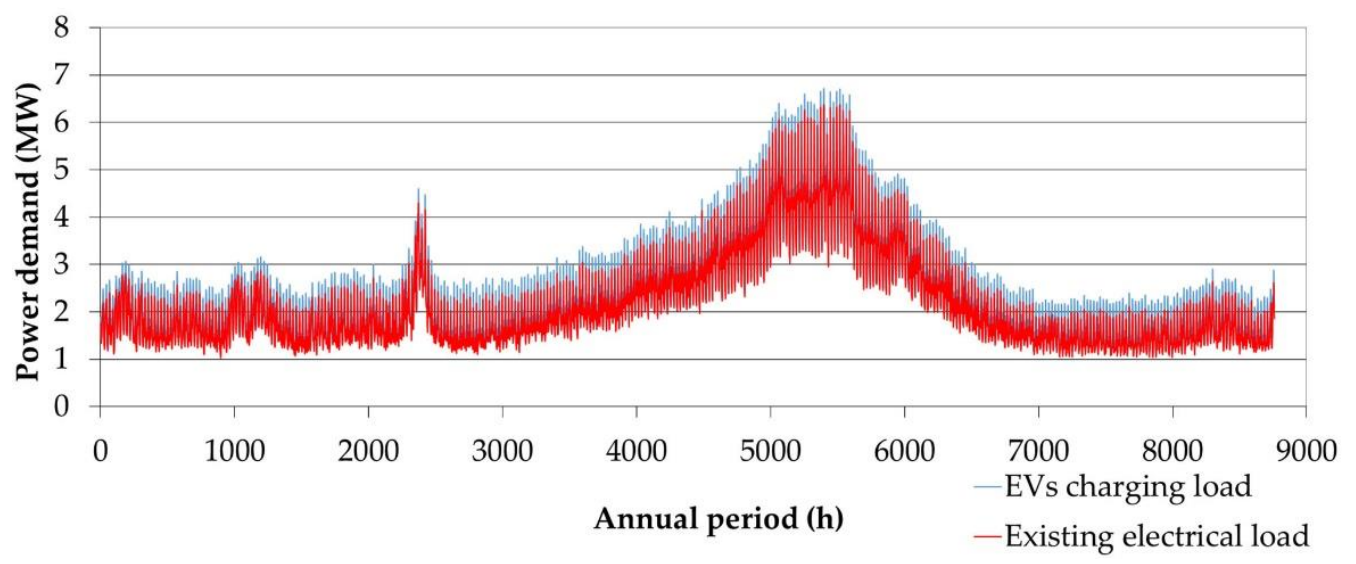

Figure 6. Final annual power demand time series with the introduction of the EV charging load.

The wind potential at the wind park's installation site was evaluated with certified wind potential measurements accomplished over a period of 14 months, from July 2016 to September 2017, covering the summer months twice, namely the crucial peak demand period. The average wind velocity during the measurement period was $9.89 \mathrm{~m} / \mathrm{s}$, classifying the available wind potential among the highest in Europe [59]. Most importantly, during July and August, namely during the peak demand period, the average monthly wind velocity was measured at 11.8 and $9.1 \mathrm{~m} / \mathrm{s}$, respectively, in 2016, and at 10.1 and $12.0 \mathrm{~m} / \mathrm{s}$, respectively, in 2017, revealing concurrency between the availability of high wind potential and the peak demand period. In Figure 7, the wind rose and the wind velocity Weibull distribution $(C=11.2 \mathrm{~m} / \mathrm{s}, \mathrm{k}=1.91)$ are presented, based on the available measurements [60]. Another important feature revealed from the wind rose graph is the almost constant wind blowing direction from the north-northeast, perpendicular to the mountain's ridge orientation. This feature, apart from the minimization of the wake shading losses, is expected to provide an important contribution to the insular grid's stability, due to the stable, scarcely fluctuating northerly winds, enabling the more secure and constant production of the wind turbines.
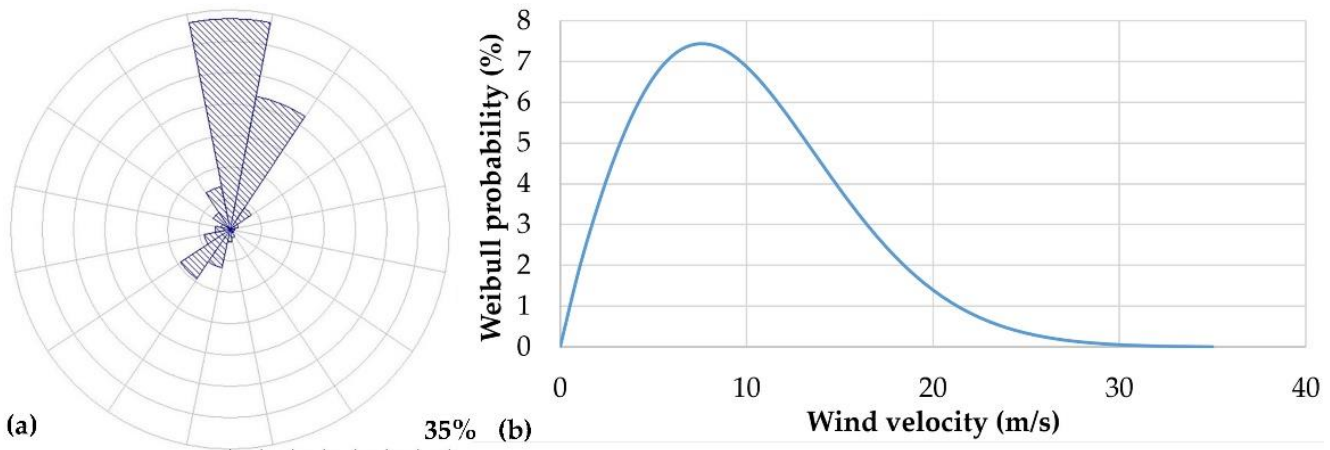

Figure 7. (a) Wind rose and (b) Weibull probability density distribution based on the executed wind potential measurements.

\section{Results}

\subsection{Planning and Sizing Results}

The annual operation of the proposed hybrid power plant on Sifnos was computationally simulated, following the previously presented operation algorithm. The hybrid power plant's sizing was established through the iterative execution of the simulation for different 
dimensioning scenarios, until the essential objective was fulfilled, namely the $100 \%$ annual electricity demand coverage of the hybrid power plant.

The size of the main components of the hybrid power plant is given below:

- Wind park: four Enercon E-82/E4 wind turbines with a nominal power of $3000 \mathrm{~kW}$ each and a rotor diameter of $82 \mathrm{~m}$, giving a total wind park power of $12 \mathrm{MW}$.

- PHS:

- $\quad$ upper reservoir with a storage capacity of $1106,057 \mathrm{~m}^{3}$ and an absolute altitude of its free surface at its upmost position of $332 \mathrm{~m}$

- $\quad$ hydroelectric power plant with four Pelton hydro turbines with a nominal power of 2.185 MW each, providing a total plant capacity of 8.74 MW

- a pump station with twelve centrifugal pumps with nominal mechanical power of 0.857 MW each, providing a total station nominal mechanical power of 10.28 MW

- two of pipelines exclusively for the transportation of water from the upper reservoir to the hydroelectric power plant and another two exclusively for the transportation of the pumped water from the sea to the upper reservoir, constructed from glass-reinforced polyester (GRP), with an inner diameter of $1 \mathrm{~m}$.

The available storage capacity of the upper reservoir in combination with the absolute altitude of its installation site offers a storage capacity of $860 \mathrm{MWh}$. Accounting for the current daily average electricity consumption, this energy storage capacity imposes an autonomy operation period of the PHS system for 16 days (full coverage of the power demand), starting from a full charge level and without any intermediate storage during this period.

The installation site of the hybrid power plant is located on the northeast coast of the island and is depicted in Figure 8.

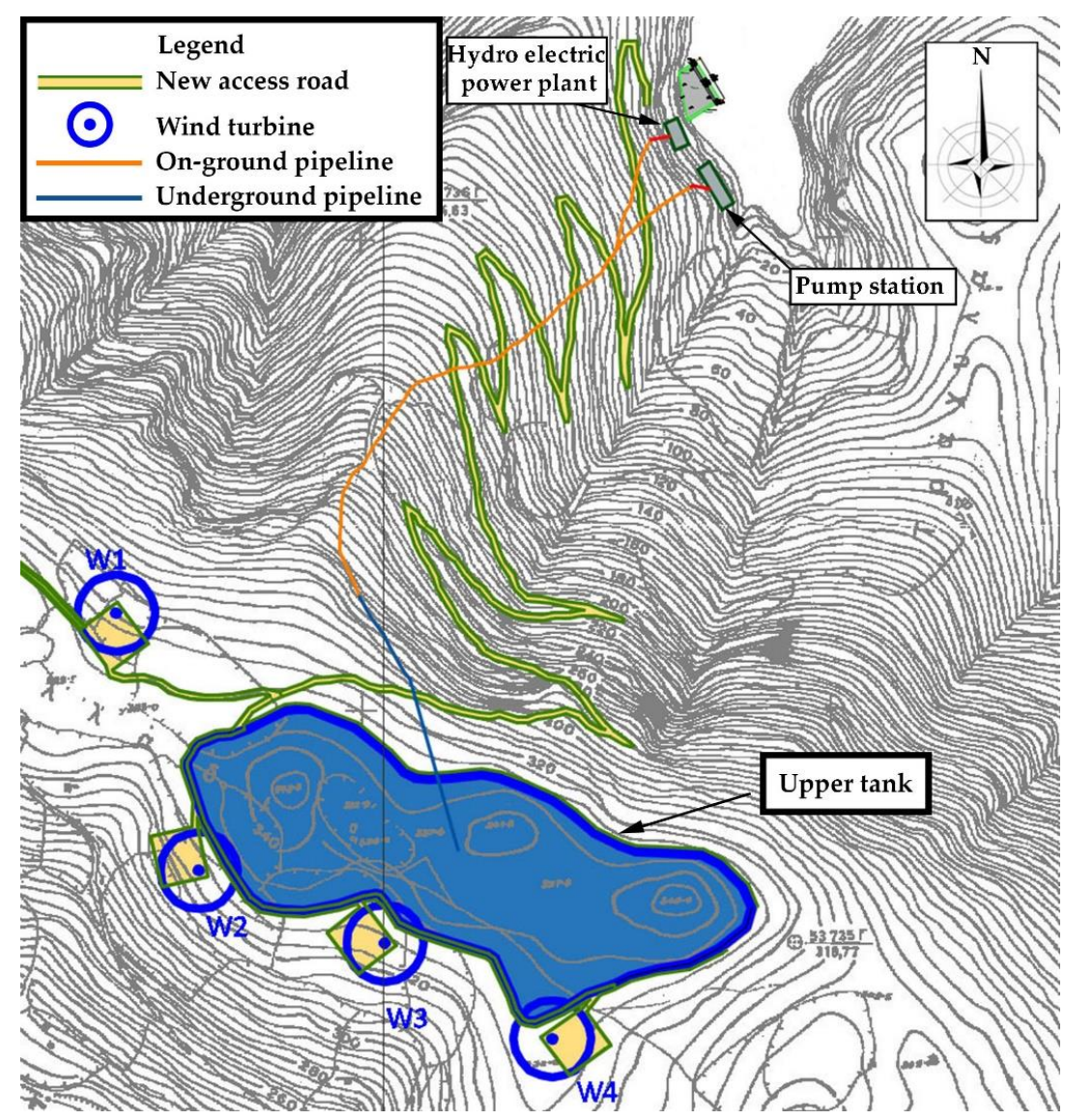

Figure 8. The siting of the hybrid power plant. 
As seen in Figure 8, the wind park is at the same installation site as the upper reservoir, a highly important feature for the minimization of the project's set-up cost and the elimination of the project's impacts on the natural environment and existing human activities. The hydroelectric power plant and the pump station are sited on the northeast coastline of the island.

The installation position combines a cluster of favorable features which make it ideal for the specific project, such as:

- the availability of a relatively flat area at the upper reservoir's installation location minimizes the required excavation works for the configuration of the upper reservoir's basin

- the mild slopes of the wind park's installation hill, without any abrupt changes in the land morphology, favor smooth wind flow, without atmospheric boundary layer detachment and shear effect (Figure 9)

- the wind park's installation position is free of physical or technical obstacles towards the sea, thus allowing unobstructed wind flow from the prevailing blowing direction (northeast) towards the turbines' rotors, without any deterioration of its kinetic energy

- the mild slopes of the penstock installation land provide easy and secure access for the pipelines' installation on the surface, avoiding the need for the construction of expensive underground tunnels

- the relatively flat area along the coastline enables its configuration for the erection of the hydroelectric power plant and the pump station without excessive land works

- the installation site is located far enough from all settlements on Sifnos and outside of any site of cultural and historical interest, as well as the Natura 2000 region found in the central and western part of the island, facilitating, in this way, the licensing process and ensuring widespread acceptance from the local community and any environmental organizations.

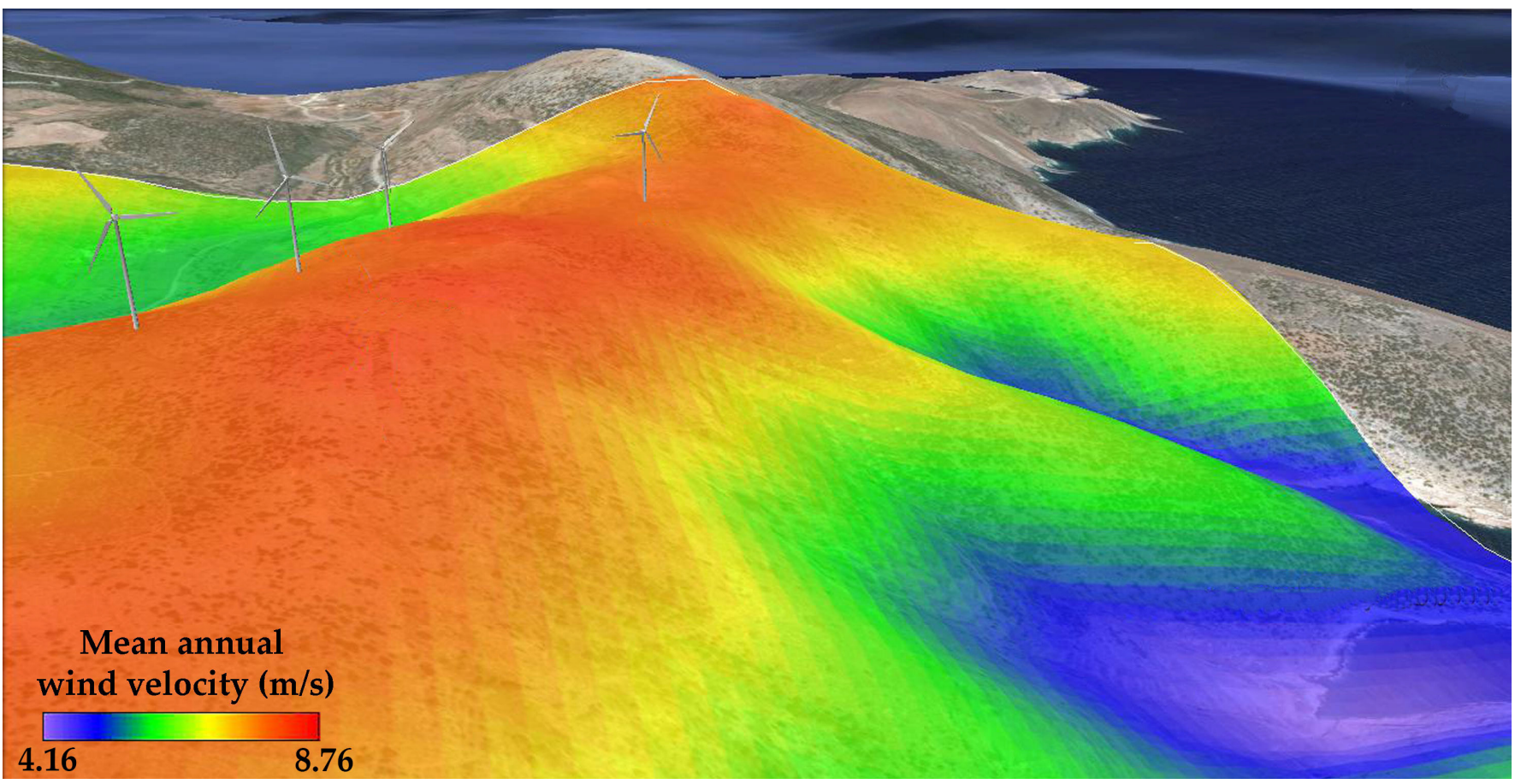

Figure 9. Siting of the wind park over a 3D annual average wind velocity background. 
The installation position was selected by the scientific team together with the founding members of the SIC. The aforementioned positive features reveal the potential when the technical expertise of experienced consultants is combined with the deep knowledge of the available territory, supplied by the local citizens, and their interest in achieving the optimum possible results of their initiative.

The results regarding the annual electricity production and storage, presented in Table 3, were calculated by integrating the corresponding annual power production or storage time series. As seen in this table, the fundamental objective of the hybrid power plant, namely the $100 \%$ coverage of the electricity demand in real time and on an annual basis, is achieved with the proposed sizing and synthesis.

Table 3. Analysis of the annual electricity production on Sifnos in 2021.

\begin{tabular}{cc}
\hline Magnitude & Amount \\
\hline Total initial annual production from the wind park (MWh) & $44,961.4$ \\
Annual direct electricity penetration from the wind park (MWh) & 4627.8 \\
Annual electricity production from the hydro turbines (MWh) & $13,946.9$ \\
Annual electricity production from the existing wind park (MWh) & 1524.7 \\
Annual electricity production from the existing photovoltaics (MWh) & 257.3 \\
Total annual electricity production (MWh) & $20,356.7$ \\
Annual electricity consumption coverage from RES (\%) & 100.0 \\
Annual electricity storage (MWh) & $21,649.9$ \\
PHS system total average annual efficiency (\%) & 66.0 \\
Annual electricity production from the wind park surplus (MWh) & $23,311.5$ \\
Annual electricity surplus percentage over the wind park's production (\%) & 51.8 \\
\hline
\end{tabular}

However, the wind park's high electricity production surplus, calculated at 23,311 MWh (51.8\% of its initial electricity production), is also observed in this table. This annual electricity surplus is the result of wind power production which can neither penetrate for direct power demand coverage, due to the maximum instant penetration percentage limit, nor be stored in the PHS system because of the fully charged upper reservoir. This electricity surplus at a first glance features as a drawback due to the hybrid power plant's oversizing, meaning that it can cope with the increasing power demand during summer. However, given the purpose and the objectives of the SEC, this additional electricity can be turned into a lever for the development of new, developmental activities on the island, thoroughly analyzed in the next section.

The annual power production synthesis graph is given in Figure 10a, while in Figure 10b, a power production synthesis graph is presented focused on a 10-day time interval during the peak demand period.

In Figure 11, the annual fluctuation of the water volume stored in the upper reservoir is depicted. The upper reservoir is full for most of the time from October to May. In summer, due to the increasing power demand, the water volume in the reservoir gradually decreases. The reservoir is never empty, and hence there is always enough water in the reservoir to address the power demand and achieve $100 \%$ annual electricity demand coverage. 


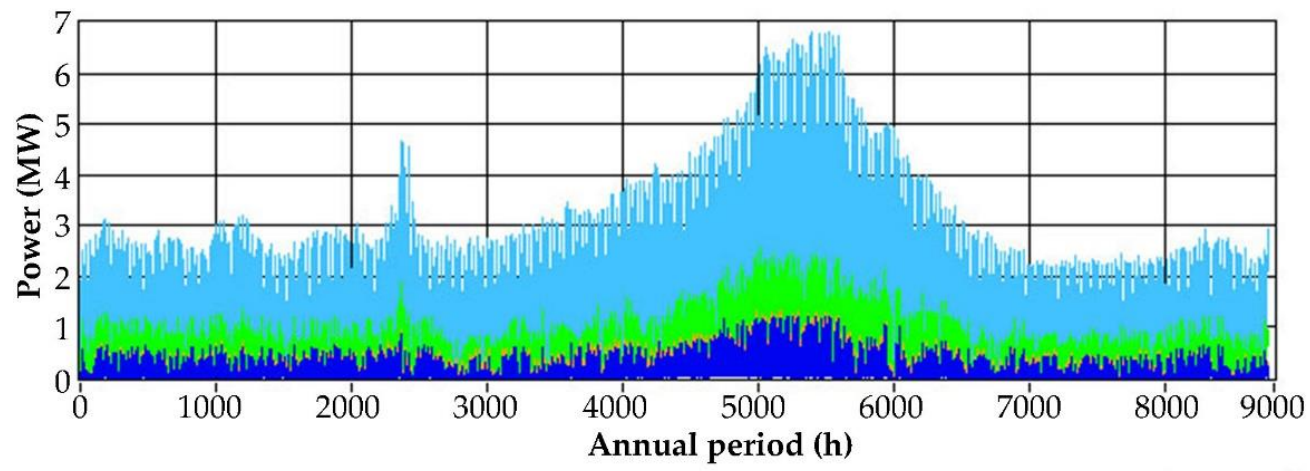

Existing wind park

Existing photovoltaics

(a)

HPP's wind park direct penetration Hydro turbines
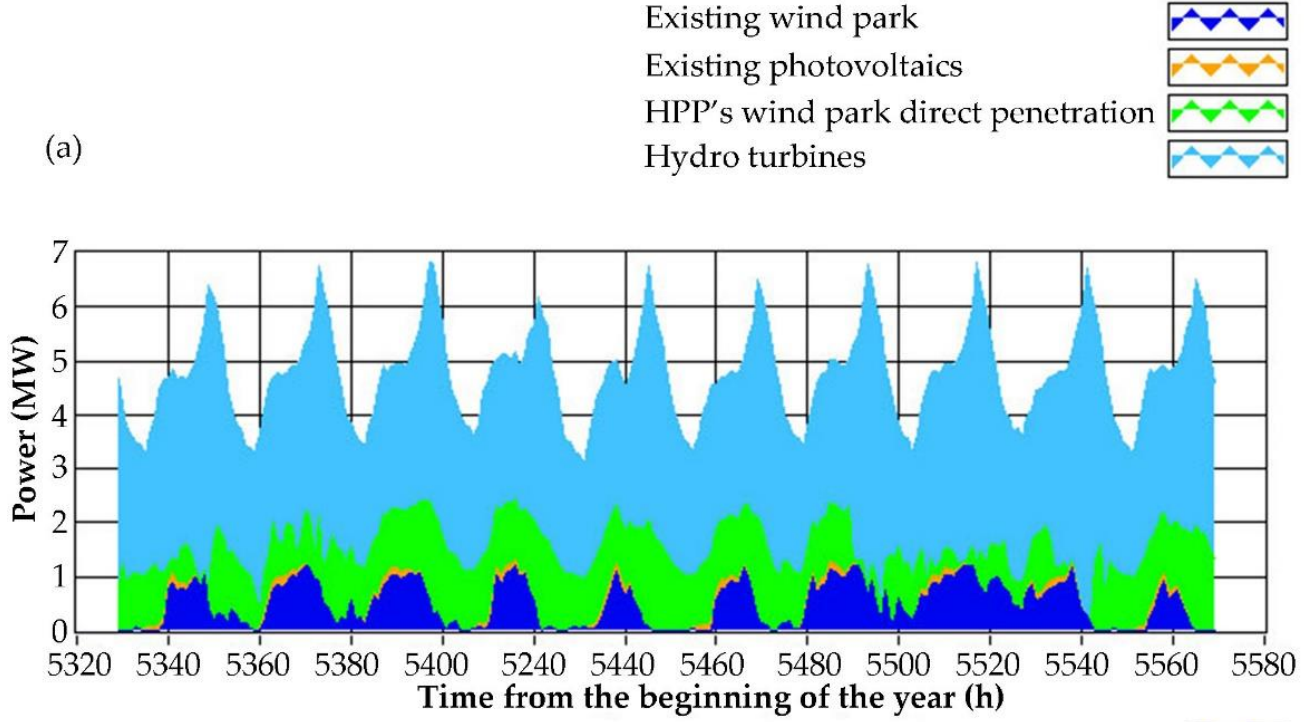

Existing wind park

Existing photovoltaics

(b)

$\mathrm{HPP}^{\prime}$ s wind park direct penetration Hydro turbines

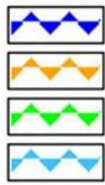

Figure 10. Power production synthesis for (a) the annual period and (b) the period from 11/8 to $20 / 8$.

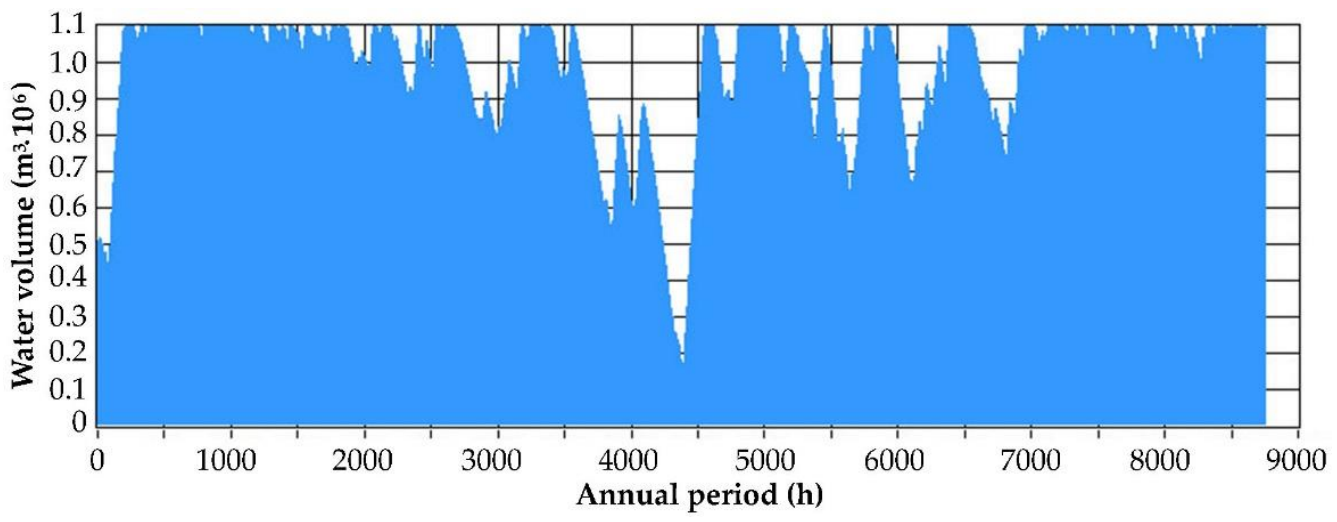

Figure 11. Annual fluctuation of the water volume stored in the PHS system upper reservoir.

\subsection{Impacts on the Natural and Human Environment}

The installation site of the hybrid power plant was selected after a thorough examination of all potential alternatives on the insular territory. This was the result of the common effort of the project's consultants and the founding members of the SIC. As already mentioned previously, the finally selected site combines several favorable features. It is outside of any potential site of interest, such as NATURA 2000 regions, natural wetlands, natural 
monuments, archaeological zones, wildlife habitats, etc., as seen in Figure 12. Additionally, 10 out of the 13 of the total settlements on Sifnos are located more than $3000 \mathrm{~m}$ away from the installation site. The nearest officially defined settlement (Agia Marina) is located $2.3 \mathrm{~km}$ away from the installation site. The nearest unofficial settlement (Troullaki) is located $1.5 \mathrm{~km}$ away.

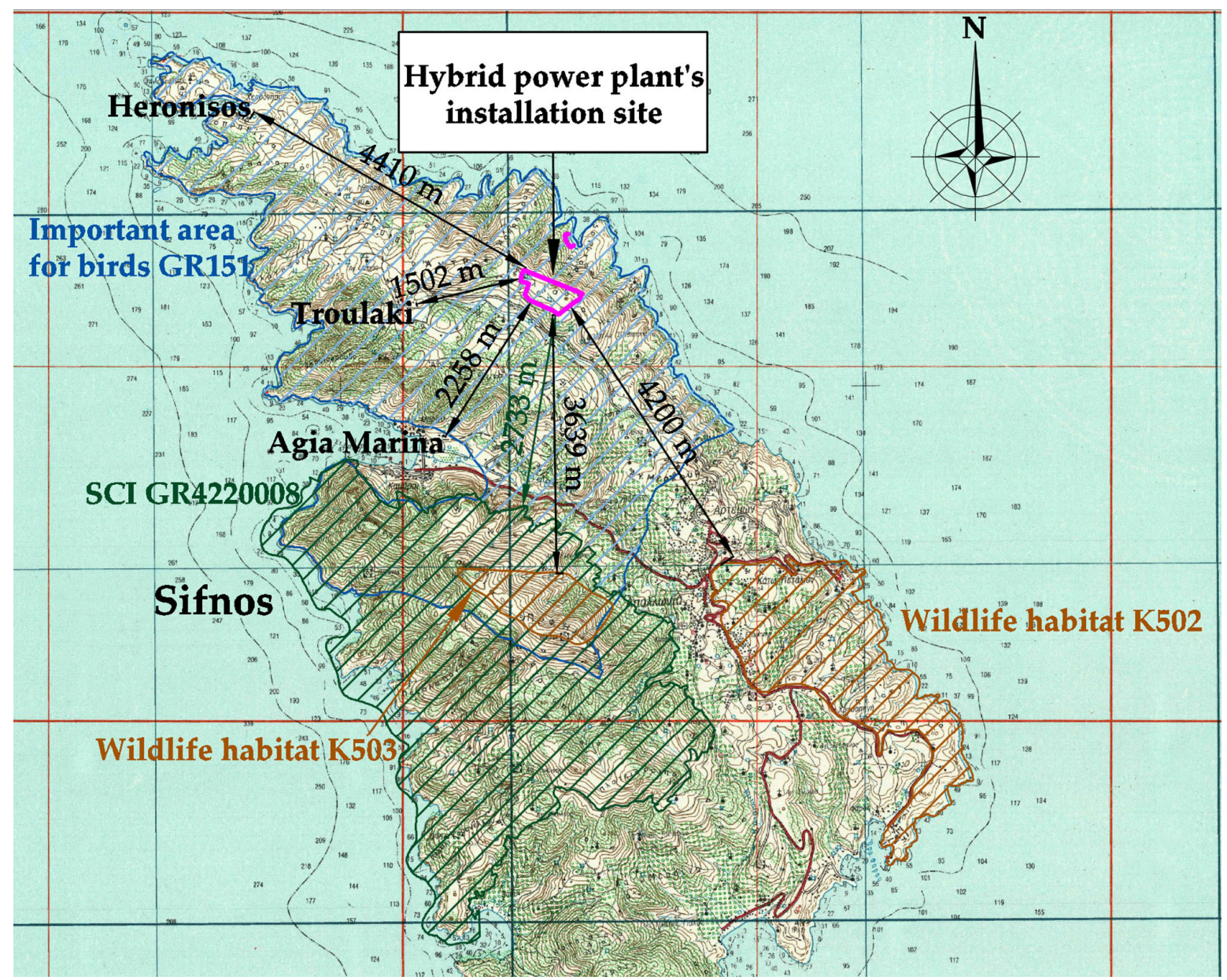

Figure 12. Distance of the hybrid power plant's installation site from the points of interest on the island.

The installation site is located inside an Important Birds Area, as declared by the Hellenic Ornithological Society (HOS), with the code number gr151 [61]. The area has not been characterized as a Special Protection Area of the NATURA 2000 network, due to the low concentration of the important bird species population (raptors) [62].

Thanks to the selected installation site, the project has negligible impacts on any existing human activities and the natural environment. The zone of visual impact is presented in Figure 13, while in Figure 14, the noise diffusion map is presented. Both calculations were executed with the use of the Wind Farm R5 software. The wind park will be visible only from the settlement of Troullaki, from a distance of $1.5 \mathrm{~km}$. There is also visual contact with Apollonia, but from a distance longer than $5 \mathrm{~km}$, and hence the impact is not considered important [63]. Additionally, maximum noise level calculated in inhabited areas due to the wind turbines operation is lower than $30 \mathrm{~dB}(\mathrm{~A})$, and hence this impact is also negligible. 


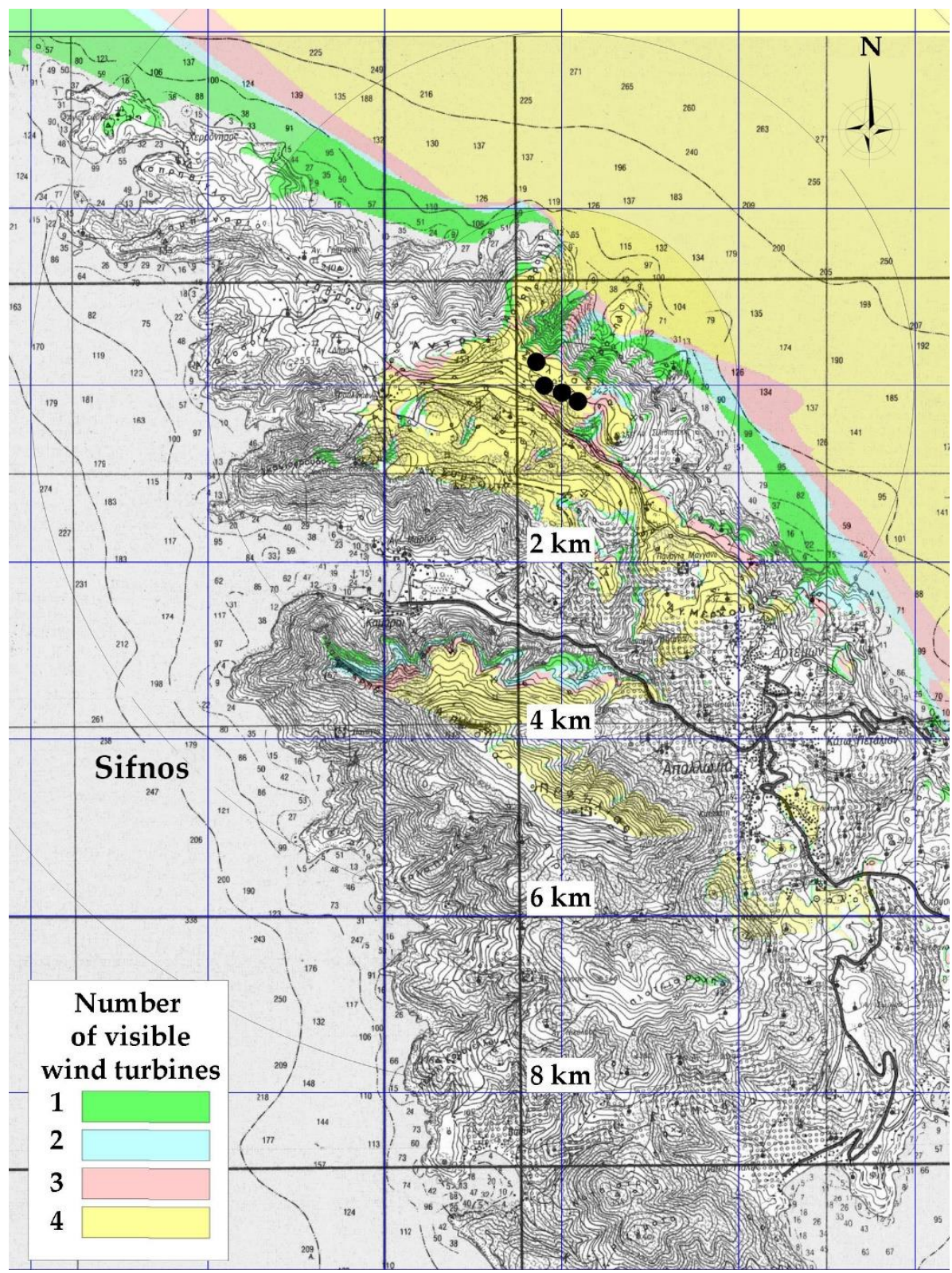

Figure 13. Zone of visual impact map of the wind park on Sifnos.

Finally, in Figure 15, the annual optical shading of the wind park on the settlement of Troullaki is depicted. The settlement, as shown in Figure 12, is located to the west of the wind park's site. Hence, any potential shading can only occur during sunrise. Indeed, as shown in Figure 15, the shading periods are restricted solely to during the early morning hours (the daily period on the $y$-axis, the annual period on the $x$-axis). Additionally, shading occurs between the 90th and the 120th day (April) and between the 220th and the 250th day of the year (August, September). In total, the settlement's shading occurs for 37 days during a year, with maximum shading time per day of $13.2 \mathrm{~min}$ and a total annual shading time $6.3 \mathrm{~h}$. These results were calculated for the worst case scenario, namely by assuming clear sky and atmosphere (no clouds, fog or airborne particles) during the specific time periods when the turbines' shadow falls on the particular settlement. This optical shading should be considered minor or even negligible, given that the wind turbine's shade fades with distance and for distances longer than $1.5 \mathrm{~km}$, it is practically imperceivable [64]. 


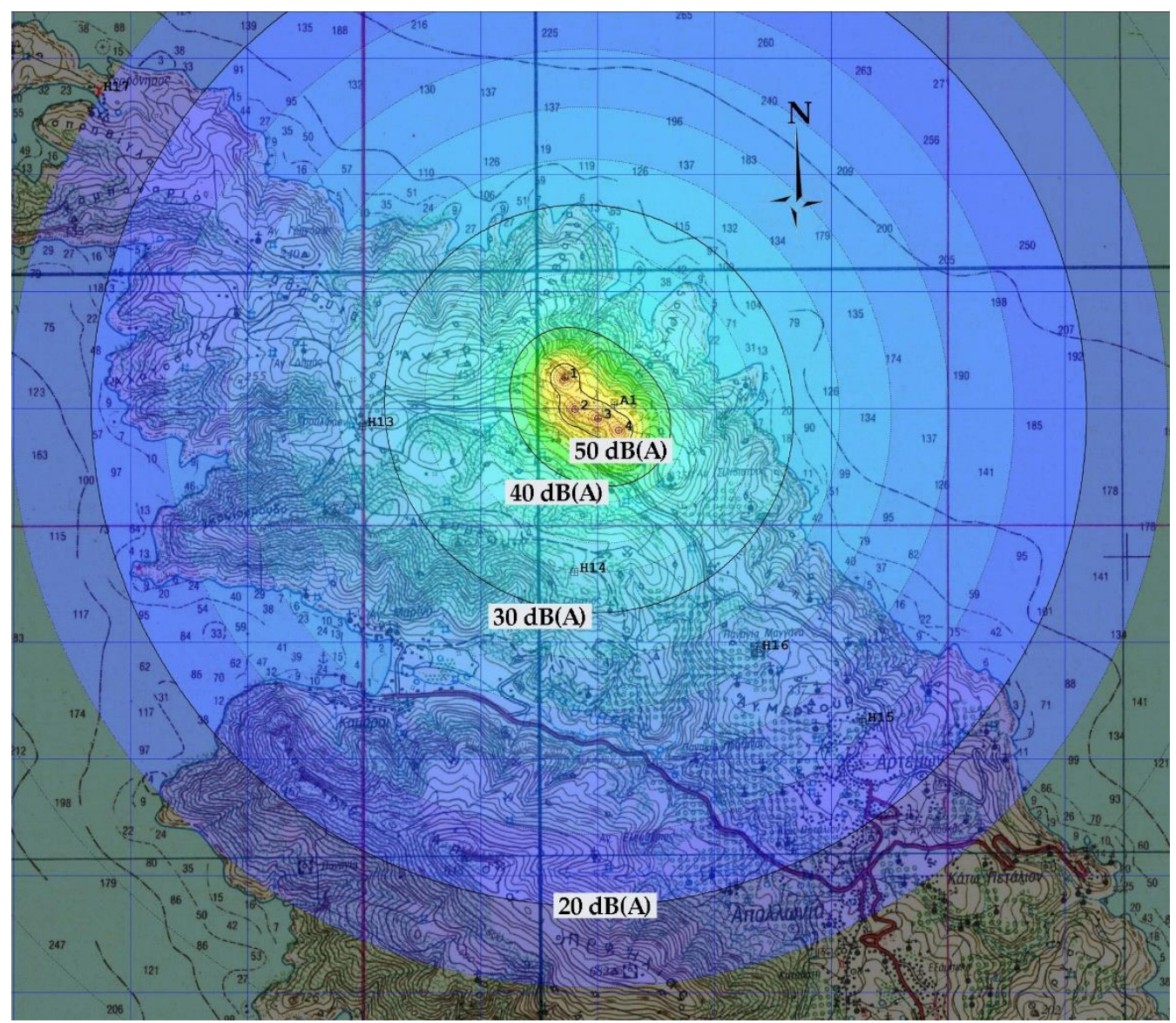

Figure 14. The wind turbines' aerodynamic noise diffusion map on Sifnos.

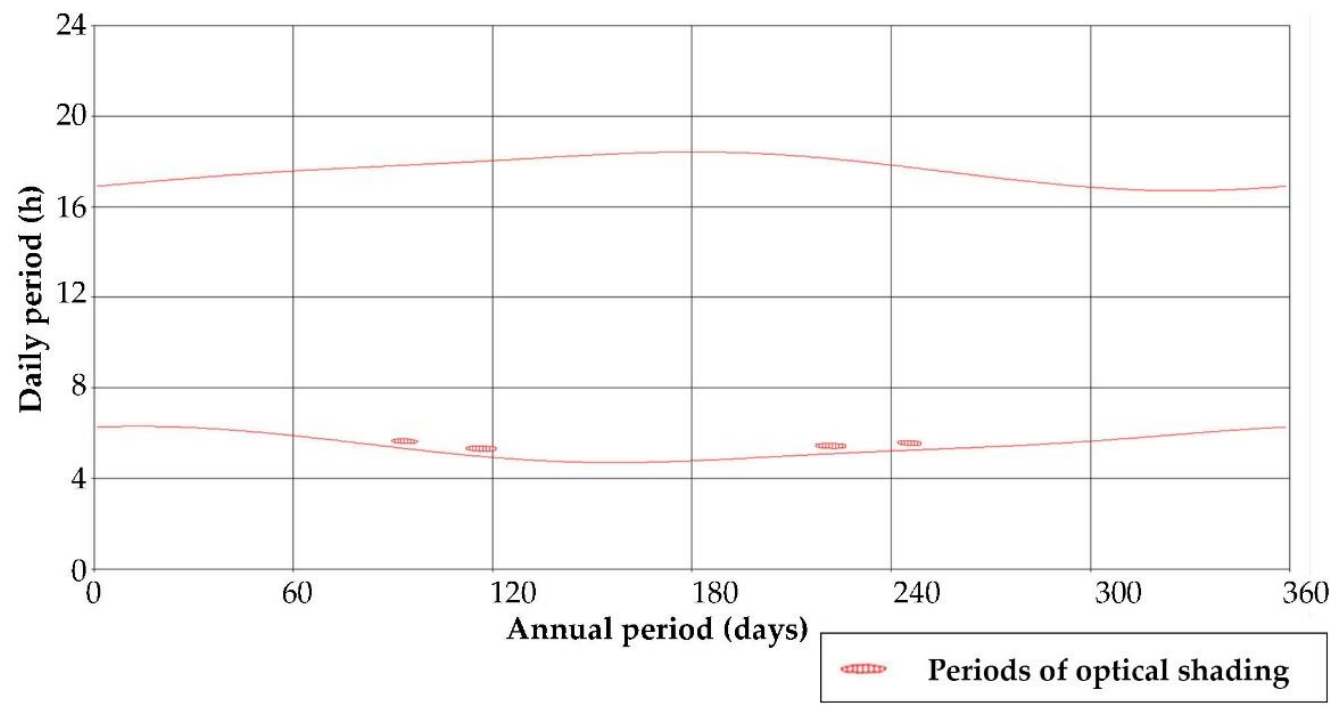

Figure 15. Annual fluctuation of the wind turbines' optical shading on the settlement of Troullaki.

The scope of this analysis is to prove that RES projects can have negligible impacts on the natural environment and human activities when once the installation site, the project's size and the optimum technologies are appropriately selected. Such results can be achieved with the collaboration of experienced consultants with the local community. 


\section{Extensions}

\subsection{Development Perspectives}

The proposed hybrid power plant can provide a multi-level contribution to the social and economic development of the local society, given that the project is implemented by the local islanders themselves, through the cooperative scheme of the Sifnos Energy Community. The tool for this multi-level contribution comes mainly from the electricity surplus produced by the hybrid plant and, in particular, its potential exploitation for specific activities which will enable full energy transition, on the one hand, and will create strong development perspectives on the other.

First of all, a major problem on Sifnos is its maritime connection with the neighboring islands, especially during winter, when the scheduled voyages are not executed on a daily basis. This problem is further intensified given that Sifnos, being a small island, does not have an airport. The produced electricity surplus can be exploited for hydrogen production, in order to be used to power a small passenger ship, with which a daily maritime transportation connection between Sifnos and the nearby islands can be established.

The hydrogen production process can be easily simulated following the steps described below. Firstly, the annual power surplus time series $\mathrm{P}_{\text {sur }}$ is introduced as calculated by the executed computational simulation. For every calculation step of duration $t$ (hourly), the following tasks are performed:

1. If $\mathrm{P}_{\mathrm{el}}$ is the electrolysis device's nominal power, then the absorbed power by the electrolysis device $\mathrm{P}_{\text {RESel }}$ will be:

$$
\begin{aligned}
\text { i. } & \text { if } \mathrm{P}_{\mathrm{sur}}>\mathrm{P}_{\mathrm{el}}, \mathrm{P}_{\mathrm{RESel}}=\mathrm{P}_{\mathrm{el}} \\
\text { ii. } & \text { if } \mathrm{P}_{\mathrm{sur}} \leq \mathrm{P}_{\mathrm{el}}, \mathrm{P}_{\mathrm{RESel}}=\mathrm{P}_{\text {sur }}
\end{aligned}
$$

2. If $\mathrm{e}_{\text {hyd }}$ is the specific electricity consumption per produced hydrogen unit of mass (typically $53.5 \mathrm{kWh} / \mathrm{kg}[65,66]$ ), the produced hydrogen mass $\mathrm{m}_{\mathrm{el}}$ will be:

$$
\mathrm{m}_{\mathrm{el}}=\frac{\mathrm{P}_{\mathrm{RESel}} \cdot \mathrm{t}}{\mathrm{e}_{\text {hyd }}}
$$

3. At the same time step, let $\mathrm{m}_{\text {cons }}$ be the consumed hydrogen mass for the needs of the passenger ship. For a passenger capacity of 100 people, an on the safe side assumption regarding the hydrogen-specific consumption is $3 \mathrm{~kg} / \mathrm{nm}$ [67].

4. The mass $m_{s t}(j)$ of hydrogen which will remain stored in the storage tank at the end of the current calculation time step j equals:

$$
m_{s t}(j)=m_{s t}(j-1)+m_{e l}-m_{\text {cons }}
$$

where $m_{s t}(j-1)$ is the remaining hydrogen's mass in the storage tank at the end of the precedent time step $\mathrm{j}-1$.

5. The new pressure in the hydrogen storage tank is calculated with the relationship:

$$
p_{\text {tank }}(j)=\frac{m_{\text {st }}(j)}{V_{\text {st }}} \cdot R \cdot T_{\text {tank }}(j)
$$

where $V_{\text {st }}$ is the volume storage capacity of the storage tank and $T_{\text {tank }}(j)$ the hydrogen temperature in the tank, which can be considered equal to the ambient temperature. $\mathrm{R}$ is the hydrogen's ideal gas constant, equal to $4124.2 \mathrm{~J} /(\mathrm{kgK})$.

6. It is examined whether the new pressure in the hydrogen tank is lower than the minimum $p_{\min }$ (e.g., 5 bar) or higher than the maximum possible $p_{\max }$ value. The following cases are distinguished:

i. If $\mathrm{p}_{\operatorname{tank}}(\mathrm{j})<\mathrm{p}_{\min }$, then:

$$
\mathrm{m}_{\text {cons }}=0
$$




$$
m_{s t}(j)=m_{s t}(j-1)+m_{e l} \text {. }
$$

ii. If $p_{\operatorname{tank}}(j)>p_{\max }$, then:

$$
\begin{gathered}
P_{\text {RESel }}=0 \\
m_{\mathrm{el}}=0 \\
\mathrm{~m}_{\mathrm{st}}(\mathrm{j})=\mathrm{m}_{\mathrm{st}}(\mathrm{j}-1)-\mathrm{m}_{\text {cons }} .
\end{gathered}
$$

iii. If $\mathrm{p}_{\min } \leq \mathrm{p}(\mathrm{j}) \leq \mathrm{p}_{\max }$, then the magnitudes of $\mathrm{P}_{\mathrm{RESel}}, \mathrm{m}_{\mathrm{el}}$, and $\mathrm{m}_{\mathrm{st}}(\mathrm{j})$ and are calculated with Relationships (18)-(21).

A circular voyage from the marina of Platis Yialos on the southern coast of Sifnos, to the marina of Pollonia on the northeast coast of Milos and then to the port of Paroikia in Paros and the port of Ermoupoli in Syros (capital of the Cyclades Prefecture) and then back to Platis Yialos (Figure 16) covers a total distance of $110 \mathrm{~nm}$. Given the hydrogen-specific consumption of $3 \mathrm{~kg} / \mathrm{nm}$, the daily amount of hydrogen required for this voyage will be $330 \mathrm{~kg}$, which, for the needs of the simulation, can be assumed to be removed from the hydrogen storage tanks at 12:00 every day.

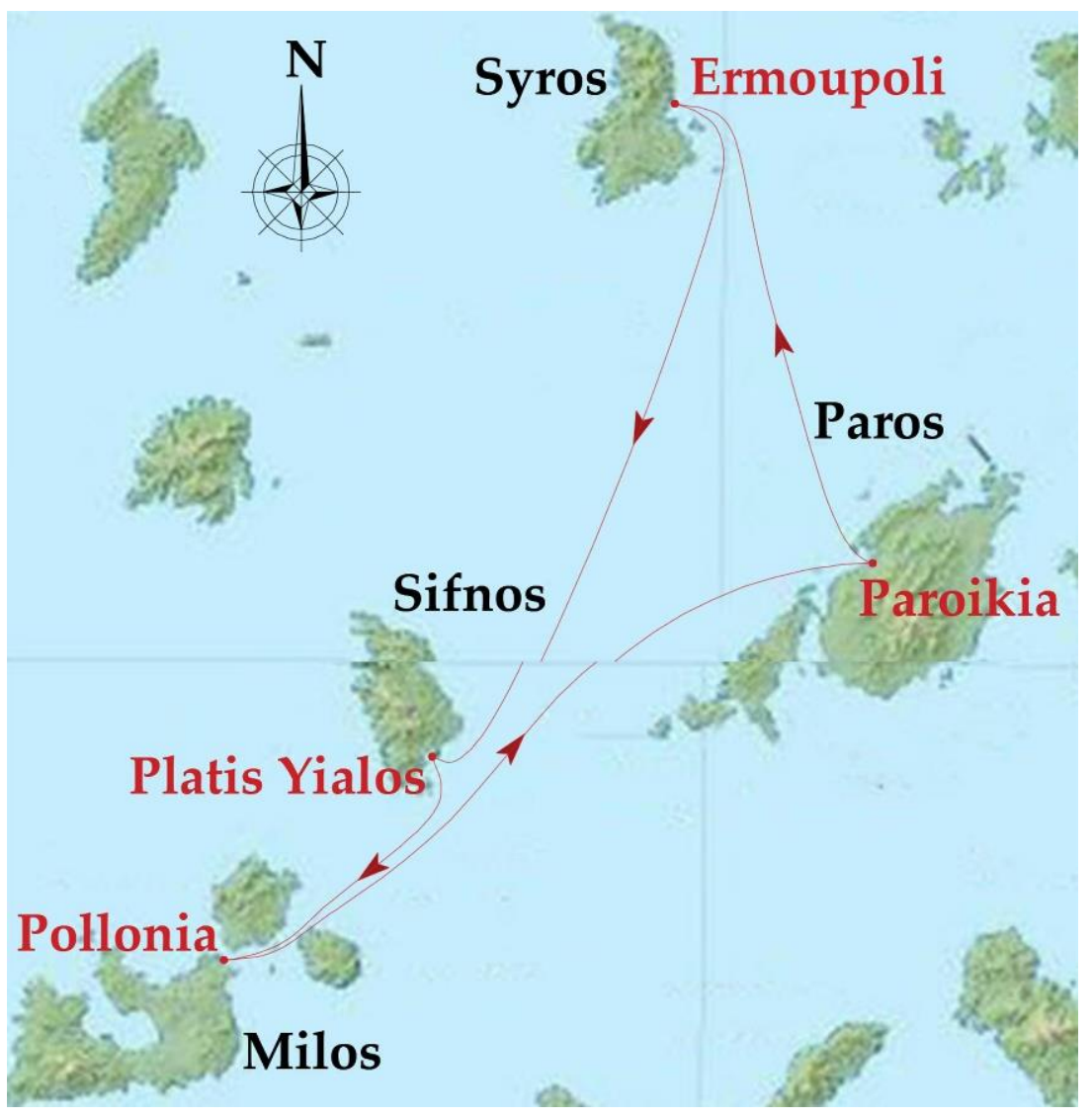

Figure 16. Map of the potential circular ship voyage for the daily maritime connection between Sifnos and the neighboring islands.

The previously presented algorithm is executed iteratively for alternative scenarios for the main components of the hydrogen production and storage plant, namely the electrolysis unit's nominal power and the storage tanks' storage capacity and nominal power. The results are summarized in Table 4. 
Table 4. Summary of results from the iterative calculation process of the hydrogen production and storage plant.

\begin{tabular}{ccccc}
\hline & Scenario 1 & Scenario 2 & Scenario 3 & Scenario 4 \\
\hline Electrolysis nominal power (MW) & 4 & 5 & 5 & 5 \\
Hydrogen tanks storage capacity (m ${ }^{3}$ ) & 500 & 500 & 400 & 500 \\
Hydrogen tanks nominal pressure (bar) & 300 & 250 & 300 & 300 \\
Hydrogen annual demand (kg) & 120,450 & 120,450 & 120,450 & 120,450 \\
Hydrogen annual supply (kg) & 118,800 & 118,800 & 118,140 & 120,450 \\
Annual electricity consumption (MWh) & 6767 & 6655 & 6597 & 6857 \\
\hline
\end{tabular}

In Figure 17, the annual pressure fluctuation in the hydrogen storage tank is presented.

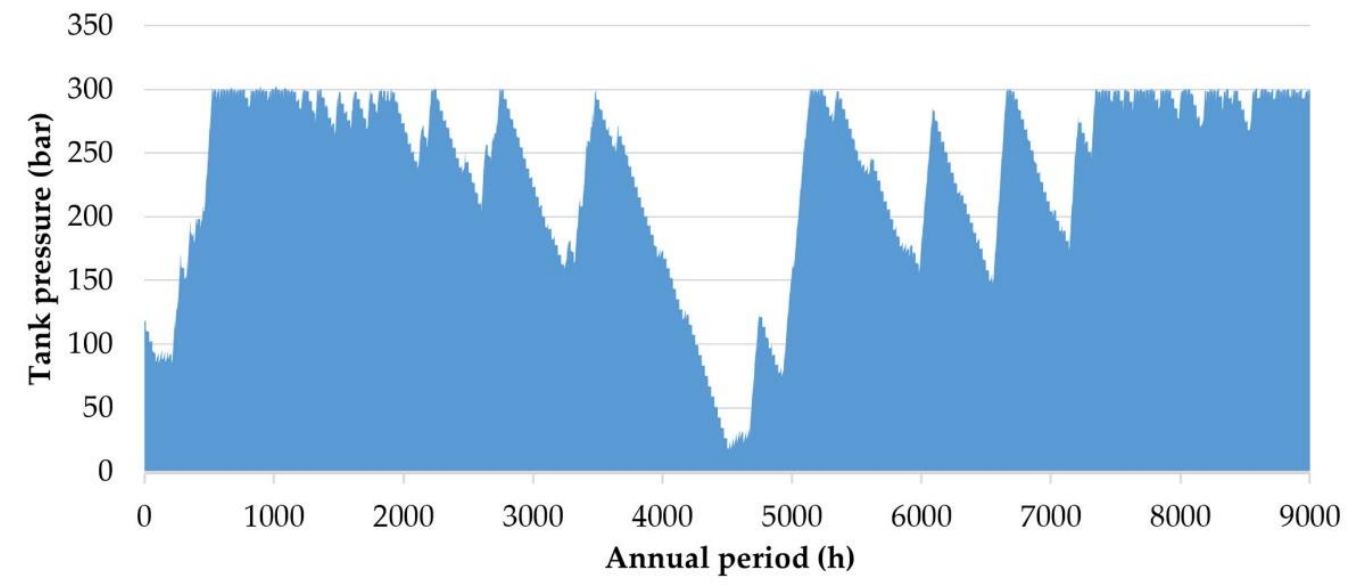

Figure 17. Annual pressure fluctuation in the hydrogen storage tank.

It is conceivable that the potential hydrogen production from the hybrid power plant's electricity surplus is capable of fueling the regular, daily, cheap, secure and sustainable maritime connection between Sifnos and the most important nearby insular centers of the Cyclades Prefecture.

Another important contribution from the hybrid plant is the remedying of the major problem regarding potable water availability, which is common for all small islands in Greece. Assuming an electricity-specific consumption of $4 \mathrm{kWh} / \mathrm{m}^{3}$ in the reverse osmosis desalination process, $1,250,000 \mathrm{~m}^{3}$ of potable water can be produced annually by exploiting $5000 \mathrm{MWh}$ from the annual electricity surplus. This amount is roughly two times higher than the current annual potable water consumption on the island. This increasing potable water availability can be the basis for the development of new professional activities, such as biological agriculture and stock farming, which today are not implemented precisely due to the lack of water [68]. These new professional activities will expand the local economy and will enable its disengagement from its high dependence on tourism.

The above perspectives demonstrate the multi-level contributions provided by the proposed hybrid power plant on Sifnos for total energy transition, through the coverage of the overall energy needs on the island and the establishment of significant developmental perspectives. At the same time, the introduction of new electrical loads into the insular grid will increase the electricity demand and will strengthen the economic viability of the hybrid plant.

Obviously, the implementation of the aforementioned plans should be approached with the construction of the required infrastructure and facilities: hydraulic networks, water storage tanks, desalination units, electrolysis units, hydrogen storage tanks and a hydrogen-powered passenger ship. All these facilities can be implemented by investing the anticipated profits from the hybrid power plant's operation, as well as by claiming funding in response to national and European calls for new innovative and pilot projects. 
Finally, with regard to the hybrid plant's contribution to local development, it should also be mentioned that it is expected to strengthen the offered tourist product on the island. The proposed project itself, acting as the main symbol of the island's energy transition, will potentially be a major tourist attraction, of course based on the condition of a proper and focused promotion of Sifnos as the first "green island" at the global scale, while achieving $100 \%$ energy transition, energy independence and democracy, and a sustainable and fair development pattern for all islanders.

\subsection{Rational Use of Energy}

The electricity production and storage from the hybrid power plant, as well as the transition to e-mobility and the aforementioned accompanied activities, will inevitably be combined with parallel energy saving actions, through calls for funding, periodically available both for public-municipal and private properties.

In insular communities in Greece, for example, more than $80 \%$ of the existing building stock is evaluated at energy performance rank D or lower [69-71]. This means that with the introduction of the appropriate energy performance upgrade measures, annual energy savings in the range of $40-60 \%$ can be achieved in buildings alone $[4,5,72]$. Equal energy savings can be achieved in potable water production and supply facilities [73,74].

A crucial issue for the successful and adequate operation of the hybrid power plant is the peak demand drop and the flattening of the daily demand profile. This can be achieved with the introduction of demand-side management (DSM) essential strategies, such as decentralized power production and storage, integrated within a new smart grid layout $[75,76]$. In Figure 18, the outcome of the introduction of small photovoltaic stations, for example in buildings' roofs, and small electrochemical storage units is presented. It was assumed that 200 families on Sifnos installed a $3 \mathrm{~kW}$ photovoltaic station each, while 100 families installed one storage device with a storage capacity of $10 \mathrm{kWh}$ and a chargedischarge capacity of $10 \mathrm{~kW}$. Electricity storage during the low demand period is performed with these decentralized storage devices, in order to be injected back in the grid during the peak demand period. The result of this combined decentralized power production and storage process is the so-called "peak demand shaving" (power demand transfer from the peak period to off-peak periods).

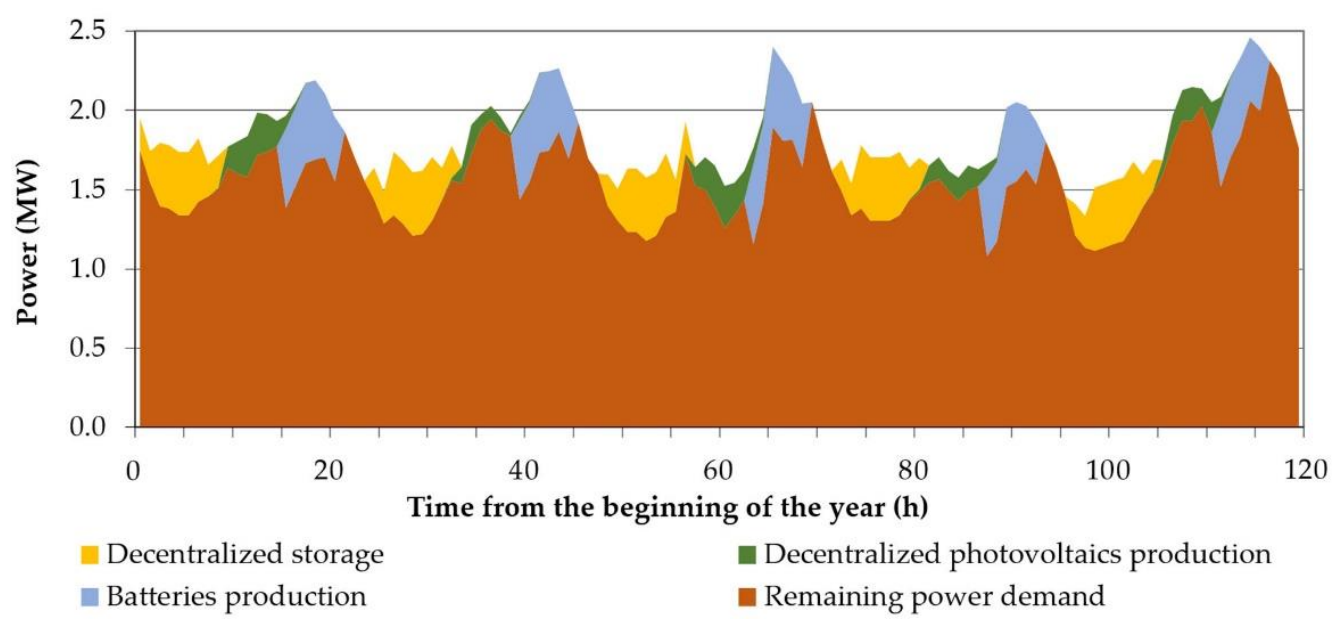

Figure 18. Peak demand shaving on Sifnos with decentralized electricity production and storage.

The decentralized electricity production from photovoltaics exhibits a payback period of 5-6 years, calculated on the basis of the avoided electricity procurement cost (with an assumed electricity price of EUR $0.17 / \mathrm{kWh}$ ). However, the installation of decentralized electricity storage devices for peak demand shaving does not today constitute an economically viable option, due to their high procurement price and short lifetime (for lithium-ion batteries, indicatively USD 400/kWh of storage capacity and 10 years, respectively). Based 
on the assumption of a probable future drop in these prices in the range of EUR $100 / \mathrm{kWh}$, then if a profit of USD $0.09 / \mathrm{kWh}$ is gained for each injected $\mathrm{kWh}$ of electricity in the insular grid during the peak demand period, and the investment will exhibit a payback period of 5 years, and hence it can be considered as an economic feasible perspective.

The overall energy transition plan with the developmental perspectives analyzed previously are graphically summarized in Figure 19.

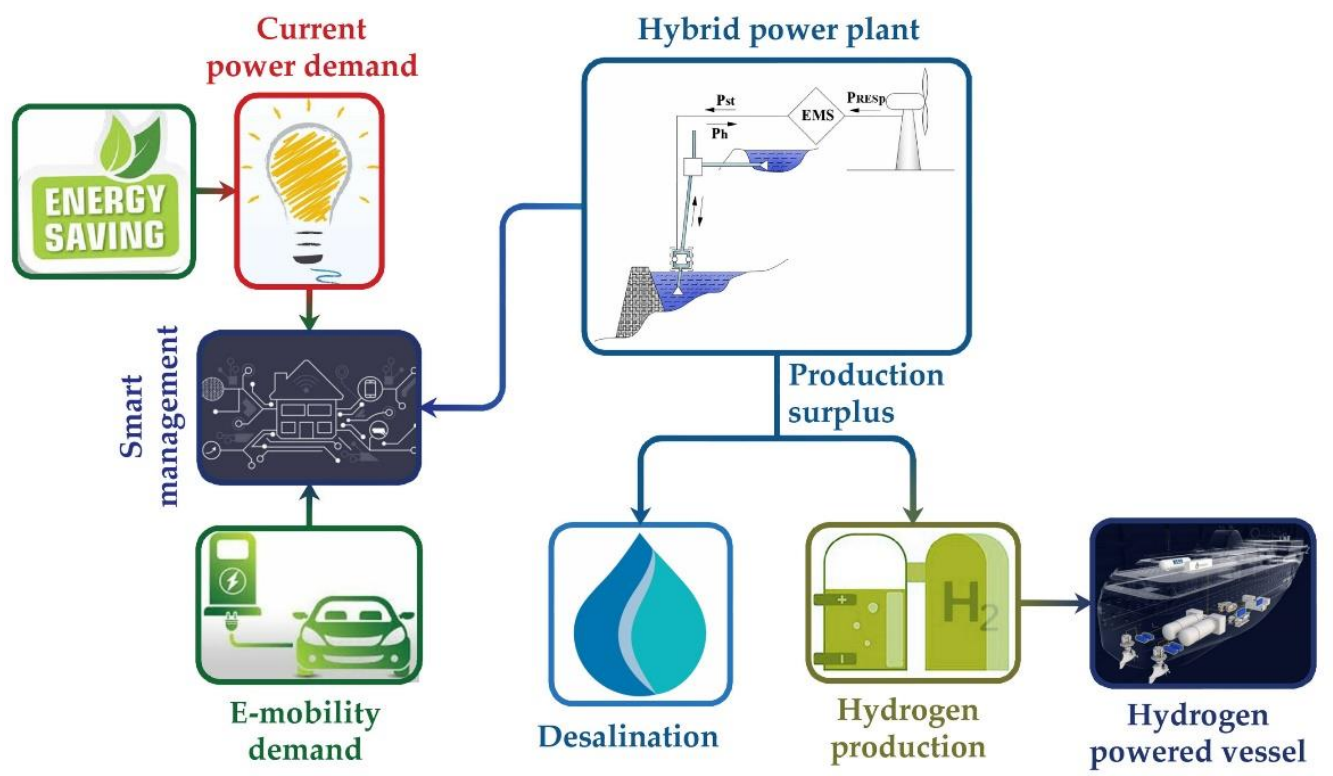

Figure 19. The overall energy transition plan on Sifnos with the opening developmental perspectives.

\section{Uncertainties}

\subsection{The Interconnection of Sifnos with the Mainland Grid}

The Independent Power Transmission Operator (IPTO), namely the utility in charge for the mainland grid in Greece, has scheduled the Greek islands' interconnection with the mainland electrical grid [77]. This inevitably raises concerns with regard to the necessity for the construction of the hybrid power plant, as the insular grid will have been strengthened as a part of a considerably larger interconnected network. The obvious question is if the storage plant will still be required or, since the insular grid will be supported by the mainland one, if a single wind park will be enough for the compensation of the electricity demand on an annual basis. Firstly, although the necessity of the interconnection of Sifnos with the mainland grid is doubtless, on the other hand, it cannot guarantee the dynamic security and the energy supply safety, given the recorded failures and faults on islands interconnected with mainland grids or with neighboring insular grids. Interconnection cable faults in the Aran Islands, Ireland (5 August 2016) [78], in Menorca, the Balearic Islands, Spain (23 May 2015 and in October 2017) [79], in Tilos, Greece (17 January 2016) and in Kassos, Greece (25 July 2003) have led to total or partial loss for 1 day in Tilos, 3 days in Aran Islands and 6 days in Kasos. It is thus concluded that the only way to ensure a secure power supply in an insular system, regardless of whether it is interconnected or not, is the maintenance of guaranteed power production on the island.

Guaranteed power production can be supplied either by keeping the thermal generators in stand-by operational mode, or with the installation of electricity storage plants. The first alternative requires that the operator uses the fixed electricity production unit (EUR 121.45/MWh on Sifnos) [8]. By accounting for the electricity production cost in the mainland grid (EUR 58.099/MWh in summer 2021 [9]) and the transportation losses, the total electricity production cost on Sifnos will be configured higher than EUR 200/MWh. Consequently, in this way, firstly the anticipated drop in the electricity production cost is not achieved, at least to expected extent, while, secondly, the electricity production on the 
island will still be dependent on imported fossil fuels, and hence the major objective of the energy transition objective for energy independence is not fulfilled.

At the same time, the necessity of the introduction of electricity storage plants even in the Greek mainland grid has been assessed by the Greek Ministry of Energy and Environment as an essential step for the secure integration of the continuously increasing installation of RES projects. The Ministry has announced the forthcoming administrative and licensing process for the installation of single electricity storage plants, namely not necessarily as a component of a hybrid power plant. The enactment of the development process for electricity storage plants, together with a relevant framework which will ensure their economic viability through the assessment of a sensible and justified electricity selling policy, will guarantee the technical feasibility and the economic viability of the hybrid power plant on Sifnos, even in the case of a potential future interconnection of this insular community with the mainland grid.

\subsection{The Electricity Selling Price}

A major parameter regarding the economic viability of the proposed project is the selling price of the electricity produced by the hybrid power plant. The impact of selling the electricity on the investment's economic efficiency, expressed via typical economic indices, is shown in Table 5. It is clarified that the total set-up cost has been estimated at EUR 37,255,000, while the funding scheme is configured, given the gathered letters of intent, at $13 \%$ private contributions and $87 \%$ banking loans, with a payback period of 15 years and a rate of $1.5 \%$. The economic indices presented in Table 5 were calculated versus private capital.

Table 5. Impact of the electricity selling price on the investment's economic efficiency.

\begin{tabular}{ccccccc}
\hline \multirow{2}{*}{$\begin{array}{c}\text { Electricity Selling } \\
\text { Price (EUR/kWh) }\end{array}$} & $\begin{array}{c}\text { Payback Period } \\
\text { (Years) }\end{array}$ & $\begin{array}{c}\text { Discounted Payback } \\
\text { Period (Years) }\end{array}$ & IRR (\%) & NPV (EUR) & ROI (\%) & ROE (\%) \\
\hline 0.18 & $>20$ & $>20$ & -1.3 & $-4,161,682$ & 1.6 & 12.4 \\
0.20 & 19.0 & $>20$ & 1.6 & $-1,373,986$ & 9.1 & 71.1 \\
0.22 & 17.0 & 18.2 & 5.6 & $2,414,699$ & 19.2 & 150.8 \\
0.24 & 15.3 & 15.9 & 9.9 & $6,203,385$ & 29.4 & 230.6 \\
0.26 & 8.2 & 9.7 & 14.5 & $9,992,071$ & 39.6 & 310.4 \\
\hline
\end{tabular}

The strong influence of the electricity selling price on the investment's economic efficiency is obvious, as expected. Following a legislation revision in Greece, performed in 2020, the selling price for the electricity produced by hybrid power plants will be defined by a relevant Ministerial Decision [80], without giving any references to the adopted algorithm, the parameters and the criteria. It is therefore conceivable that the implementation of this highly promising project on Sifnos, with all these developmental perspectives mentioned and justified in this article, remains unsure as long as the electricity selling price has not been defined.

According to the data presented in Table 5, the investment's economic viability is ensured with a selling price for the produced electricity in the range of EUR $0.26 / \mathrm{kWh}$. This price is $30 \%$ higher than the electricity production-specific cost of EUR 200/MWh, which refers to the operation of the interconnected grid of Sifnos in the future, assuming electricity production cost in the mainland system in the range configured until summer 2021. This scenario also imposes the maintenance of the existing thermal generators in stand-by operation mode. However, given the abrupt and significant electricity production cost increase recorded during the last months of 2021, the average electricity procurement price for the final consumers in Greece was configured at $0.25 \mathrm{EUR} / \mathrm{kWh}$ in December 2021 [81]. This justifies the configuration of the electricity selling price at the aforementioned value, which ensures the project's viability. 
It must be also noted that it is adequate to maintain the aforementioned selling price for as long as the payback period of the banking loans will last, namely for 15 years. Once the banking monetary obligations have been fulfilled, the electricity selling price can be reduced to the level of EUR $0.15 / \mathrm{kWh}$.

It is thus proved that with the proposed hybrid power plant, the minimum possible electricity production cost and selling price for the final consumer can be achieved, with concurrent establishment of a guaranteed power production process on the island based on RES and the total independence of imported energy sources. At the same time, a cluster of developmental perspectives is offered for the local insular community. Finally, according to the estimated set-up cost of the storage plant (EUR 25,800,000) and the achieved energy storage capacity in the upper reservoir $(860 \mathrm{MWh})$, the set-up levelized cost of the PHS system is calculated at EUR $0.30 / \mathrm{kWh}$ of storage capacity.

A summary of the aforementioned uncertainties regarding the implementation of the hybrid power plant is given in Table 6.

Table 6. Summary and evaluation of the uncertainties on the hybrid power plant implementation.

\begin{tabular}{|c|c|c|c|c|}
\hline Uncertainty & Probability & Potential Risk & Impact & Proposed Risk-Mitigation Measures \\
\hline $\begin{array}{l}\text { Electrical } \\
\text { interconnection of } \\
\text { Sifnos }\end{array}$ & $\begin{array}{l}\text { High } \\
\text { (given the IPTO plans } \\
\text { and announcements) }\end{array}$ & $\begin{array}{l}\text { Unnecessary } \\
\text { construction of the } \\
\text { hybrid power plant }\end{array}$ & Low & $\begin{array}{l}\text { The necessity of storage plants } \\
\text { increases even for the mainland grid } \\
\text { with the increase in the installation of } \\
\text { RES projects }\end{array}$ \\
\hline $\begin{array}{l}\text { Electricity selling } \\
\text { price from the } \\
\text { hybrid power plant }\end{array}$ & $\begin{array}{l}\text { Medium } \\
\text { (given the necessity for } \\
\text { both cheap electricity } \\
\text { and economic viability } \\
\text { of the project) }\end{array}$ & $\begin{array}{l}\text { Effect on the } \\
\text { economic viability of } \\
\text { the project }\end{array}$ & High & $\begin{array}{l}\text { The Greek state should realise the } \\
\text { necessity of supporting these projects } \\
\text { with guaranteed selling prices }\end{array}$ \\
\hline
\end{tabular}

\section{Conclusions}

The Sifnos Energy Community, through its initiative for rational and effective energy transition in the island, gained the distinction of the declaration of Sifnos as one of the six pilot islands of the European Commission. The hybrid power plant presented in this article features as the main symbol of energy transition on Sifnos. It exhibits three main innovative points, which designate it at the global level as a unique pilot project:

- It is the first project involving a hybrid power plant based on the combined operation of a wind park and PHS system operating with seawater.

- It is the first project with a sizing which aims at $100 \%$ electricity demand coverage in an autonomous, non-interconnected insular electrical system.

- It is the first project which aims at $100 \%$ coverage of all final energy needs in an autonomous, non-interconnected island, implemented by a local energy cooperative scheme.

The selected technologies, namely the wind park and the PHS system, are the only ones that can guarantee normal, secure and economically viable energy transition on the island. The sizing of the PHS system offers a storage capacity of $860 \mathrm{MWh}$, which imposes an autonomy operation period of 16 days, given the daily average electricity consumption. It also exhibits remarkably low levelized set-up cost, calculated in the range of EUR $30 / \mathrm{kWh}$ of storage capacity.

The annual operation of the examined hybrid power plant was computationally simulated adopting an annual power demand time series, introducing the expecting power demand for full transition to e-mobility on the island. Through this process, it was shown that the hybrid power plant with the proposed sizing can fully address the electricity power demand on Sifnos, while at the same time maintaining the power production from the already installed and operating wind park and decentralized small photovoltaic stations. All of these power plants together offer a clear 100\% annual electricity demand coverage. 
The hybrid power plant's impacts on the natural environment and the human activities are almost eliminated. This is practically achieved with the proper siting of the system's components. The installation site was selected in cooperation between the scientific team and the founding members of the Sifnos Island Cooperative. Through this collaboration, both the technical parameters and the local environment sensitivities were considered, leading to an excellent result, both regarding the achievement of the project's objectives and the elimination of any potential impacts.

Beyond its purpose as a power production plant, the project offers a wide range of developmental perspectives for the local community. These perspectives can be mainly approached through the exploitation of the remarkable annual energy surplus for potable water production with new desalination plants and hydrogen production which can be used for powering a new passenger vessel which will facilitate the daily maritime connection between Sifnos and its neighboring larger islands. In this way, the main issue of insularity with regard to the regular, secure and cheap transportation connection of Sifnos throughout the year is once and forever solved using a sustainable and environmentally friendly approach. The sizing of the hydrogen production and storage plant was established based on the computational simulation of its annual operation, proving the feasibility of the proposed perspective. The project is finally anticipated to provide a significant contribution to the touristic visibility of the island, based on the condition of a proper promotion campaign of the island as the first truly green island in the world.

Additionally, with the proposed project, the island will have a guaranteed power production plant installed in the insular territory, based on the exploitation of RES, which can ensure a secure energy supply and the improvement of the electrical grid's dynamic security and stability. The plant's ancillary services will be further strengthened with the anticipated implementation of parallel, accompanying activities and projects on the island, such as the execution of peak shaving and load shifting with decentralized power production and storage, supported by the development of a local smart grid, or the introduction of energy-saving measures in all sectors on the island (residences, municipal and tourist facilities, etc.). All of these measures will lead to the reduction in both the electricity production and, more importantly, the power demand drop, offering the margin for the more flexible operation of the hydro turbines and further strengthening the overall electrical system's stability.

The electricity interconnection of Sifnos with the mainland grid cannot ensure the electricity supply's security and the insular grid's stability without the maintenance of guaranteed power production on the island. The only way to do this in the frame of energy transition, namely without the use of thermal power plants, is the proposed hybrid power plant. At the same time, the necessity for electricity storage has been officially recognized by the Greek state also for the mainland system. The relevant legislation framework is already adapted, in order to support the installation and ensure the feasibility and viability of storage plants on the Greek mainland and in insular grids.

A crucial parameter to ensure the hybrid power plant's economic viability, which will actually enable the construction of the project and the fulfillment of all of the above objectives and perspectives, is the electricity selling price, which still remains unknown. With a price of EUR $0.26 / \mathrm{kWh}$, the investment's payback period is calculated at 8 years. Given the recent significant increase in the electricity production cost and its procurement prices for the final consumers, this price has become highly competitive. This price can be reduced to in the range of EUR $0.15 / \mathrm{kWh}$ after 15 years of normal operation, namely after the payback of the banking loans.

Conclusively, the proposed hybrid power plant is the only way to achieve the two fundamental objectives of energy transition, set also as essential targets of the scheduled interconnection of the island with the mainland grid:

- the significant reduction in the electricity production specific cost

- the elimination of the dependency of the insular power system on thermal generators and imported fossil fuels. 
Summarizing the above, this article proves that energy transition represents an approach for sustainable and viable development for insular communities, starting from local citizens. It proves that energy transition can constitute the lever for social and economic development for all, once the optimum technologies are utilized at the appropriate scale, aiming to cover all alternative final energy uses (electricity, onshore and offshore transportations), sited properly to avoid any impacts on and disturbances to the natural and human environment and, most importantly, with the active involvement and participation of the local community.

Sifnos anticipates undertaking a pioneering role regarding energy transition for all European islands and beyond. The successful implementation of the proposed project and all of the accompanying activities is a target for the global insular community. Such initiatives from local cooperative schemes can be the basis for decentralized economic and social development for insular communities, leading, eventually, to the sustainable and stable recovery of national economies.

Author Contributions: Conceptualization, A.D., Y.G. and D.A.K.; methodology, D.A.K. and Y.G.; software, D.A.K.; validation, D.A.K. and E.D.; formal analysis, D.A.K. and E.D.; investigation, D.A.K., Y.G. and A.D.; resources, A.D. and Y.G.; data curation, E.D.; writing—original draft preparation, D.A.K.; writing—review and editing, D.A.K. and E.D.; visualization, D.A.K.; supervision, D.A.K.; project administration, A.D., Y.G.; funding acquisition, A.D., Y.G. All authors have read and agreed to the published version of the manuscript.

Funding: This research was funded by SIFNOS ENERGY COMMUNITY, grant date: 12 February 2016.

Institutional Review Board Statement: Not applicable.

Informed Consent Statement: Not applicable.

Data Availability Statement: Not applicable.

Acknowledgments: Warmest thanks to HEDNO for supplying the data regarding the current operation of the insular grid on Sifnos, to the Municipality of Sifnos for supplying data regarding the existing status of the island and the Sifnos Energy Community for the assignment and the funding of the project.

Conflicts of Interest: The authors declare no conflict of interest.

\section{Abbreviations}

$\begin{array}{ll}\text { APP } & \text { Autonomous Power Plant } \\ \text { CETA } & \text { Clean Energy Transition Agenda } \\ \text { DSM } & \text { Demand Side Management } \\ \text { EU } & \text { European Union } \\ \text { EVs } & \text { Electrical Vehicles } \\ \text { GRP } & \text { Glass Reinforced Polyester } \\ \text { HEDNO } & \text { Hellenic Electricity Distribution Network Operator SA } \\ \text { HOS } & \text { Hellenic Ornithological Society } \\ \text { HPP } & \text { Hybrid Power Plant } \\ \text { IPTO } & \text { Independent Power Transmission Operator } \\ \text { PHS } & \text { Pumped Hydro Storage } \\ \text { RES } & \text { Renewable Energy Sources } \\ \text { RUE } & \text { Rational Use of Energy } \\ \text { SEC } & \text { Sifnos Energy Community } \\ \text { SIC } & \text { Sifnos Island Cooperative }\end{array}$




\section{Nomenclature}

a maximum RES power penetration percentage versus the current power demand

$\mathrm{H}_{\mathrm{h}} \quad$ the total water falling head

$\mathrm{H}_{\mathrm{P}} \quad$ the total pumping head

$\mathrm{j} \quad$ the current time calculation step

$\mathrm{P}_{\mathrm{d}} \quad$ power demand

$\mathrm{P}_{\text {drem }} \quad$ the remaining power demand

$\mathrm{P}_{\mathrm{h}} \quad$ the electricity power production from the hydro turbines

$P_{\text {RES }} \quad$ power production from the RES unit (wind park)

$P_{\text {RESav }} \quad$ the available power for storage

$P_{\text {RESp }} \quad$ RES power penetration for the power demand direct coverage

$P_{\text {st }} \quad$ the power storage

$P_{\text {sur }} \quad$ the wind power production surplus

$P_{\text {th }} \quad$ the electricity power production from the thermal generators

$\mathrm{t}$ duration of the time calculation step

$\mathrm{V}_{\max } \quad$ the upper reservoir's maximum capacity

$\mathrm{V}_{\text {min }}$ the minimum water volume which is always contained in the reservoir, due to constructive limitations

$\mathrm{V}_{\mathrm{st}}(\mathrm{j}) \quad$ the remaining water volume the PHS upper reservoir at the end of the current time calculation step

$\mathrm{V}_{\mathrm{st}}(\mathrm{j}-1)$ the remaining water volume the PHS upper reservoir at the end of the previous time calculation step

$V_{\mathrm{P}} \quad$ the water volume required to be pumped in the PHS upper reservoir, so as the available for storage power $\mathrm{P}_{\mathrm{RESav}}$ for a time step of duration $\mathrm{t}$ can be stored

$\mathrm{V}_{\mathrm{T}} \quad$ the water volume required to be supplied from the upper reservoir, so as the remaining power demand $\mathrm{P}_{\mathrm{d}}-\mathrm{P}_{\mathrm{RESp}}$ for a time step of duration $\mathrm{t}$ can be covered by the hydro turbines

$\gamma \quad$ the water specific weight

$\eta_{\mathrm{h}} \quad$ the hydro turbines' average efficiency

$\eta_{\mathrm{P}} \quad$ the pumps' average efficiency

\section{References}

1. Wikipedia: Sifnos. Available online: https://el.wikipedia.org/wiki/\%CE\%A3\%CE\%AF\%CF\%86\%CE\%BD $\%$ CE $\%$ BF $\%$ CF $\% 82$ (accessed on 16 November 2021).

2. Hellenic Statistical Authority: Population and Social Conditions. Available online: https://www.statistics.gr/en/statistics/pop (accessed on 16 November 2021).

3. Hellenic Statistical Authority: Greece in Figures. Available online: https://www.statistics.gr/en/greece-in-figures (accessed on 16 November 2021).

4. Katsaprakakis, D.A.; Zidianakis, G.; Yiannakoudakis, Y.; Manioudakis, E.; Dakanali, E.; Kanouras, S. Working on Buildings' Energy Performance Upgrade in Mediterranean Climate. Energies 2020, 13, 2159. [CrossRef]

5. Katsaprakakis, D.A.; Georgila, K.; Zidianakis, G.; Michopoulos, A.; Psarras, N.; Christakis, D.G.; Condaxakis, C.; Kanouras, S. Energy upgrading of buildings. A holistic approach for the Natural History Museum of Crete, Greece. Renew. Energy 2017, 114, 1306-1332. [CrossRef]

6. Clean Energy for EU Islands. Community. Clean Energy Transition Agenda: Sifnos. Available online: https://euislands.eu/ index.php/document/clean-energy-transition-agenda-sifnos (accessed on 16 November 2021).

7. Directive on Buildings' Energy Performance. Official Governmental Gazette 2367B' /12-7-2017. Available online: http:/ t tdm.tee. gr/wp-content/uploads/2017/07/fek_12_7_2017_egrisi_kenak.pdf (accessed on 23 December 2021).

8. Hellenic Electricity Distribution Network Operator. Technical and Economic Facts on the Autonomous Electrical System of Sifnos, Athens 2016; Technical report provided for the Sifnos Energy Community after a relevant request; Sifnos Energy Community: Sifnos, Greece, 2016.

9. Independent Power Transmission Operator. Average Electricity Procurement Price in the Green Mainland Interconnected System. Available online: https://www.admie.gr/sites/default/files/attached-files/type-file/2021/11/202012-Mesostathmiki_Timi_ Agoras_Hlektrikhs_energeias_sto_Diasyndedemeno_Systima_v3.pdf (accessed on 16 November 2021).

10. Katsaprakakis, D.A.; Voumvoulakis, M. A hybrid power plant towards $100 \%$ energy autonomy for the island of Sifnos, Greece Perspectives created from energy cooperatives. Energy 2018, 161, 680-698. [CrossRef]

11. Financial Postman. RES: First Energy Sources in Greece. Available online: https://www.ot.gr/2021/04/29/energeia/proti-pigienergeias-oi-ape-stin-ellada/ (accessed on 7 February 2022). 
12. Cherp, A.; Vinichenko, V.; Jewell, J.; Brutschin, E.; Sovacool, B. Integrating techno-economic, socio-technical and political perspectives on national energy transitions: A meta-theoretical framework. Energy Res. Soc. Sci. 2018, 37, 175-190. [CrossRef]

13. Singh, H.V.; Bocca, R.; Gomeza, P.; Dahlke, S.; Bazilian, M. The energy transitions index: An analytic framework for understanding the evolving global energy system. Energy Strategy Rev. 2019, 26, 100382. [CrossRef]

14. European Commission. Directive (EU) 2018/2001 of the European Parliament and of the Council of 11 December 2018 on the Promotion of the Use of Energy from Renewable Sources. Available online: https:/ / eur-lex.europa.eu/legal-content/EN/TXT/ ?uri=CELEX\%3A32018L2001 (accessed on 16 November 2021).

15. European Commission. Directive (EU) 2018/844 of the European Parliament and of the Council of 30 May 2018 Amending Directive 2010/31/EU on the Energy Performance of Buildings and Directive 2012/27/EU on Energy Efficiency. Available online: https:/ / eur-lex.europa.eu/legal-content/EN/TXT/?uri=uriserv\%3AOJ.L_.2018.156.01.0075.01.ENG (accessed on 16 November 2021).

16. Kapsali, M.; Anagnostopoulos, J.S.; Kaldellis, J.K. Wind powered pumped-hydro storage systems for remote islands: A complete sensitivity analysis based on economic perspectives. Appl. Energy 2012, 99, 430-444. [CrossRef]

17. Bueno, C.; Carta, J.A. Wind powered pumped hydro storage systems, a means of increasing the penetration of renewable energy in the Canary Islands. Renew. Sustain. Energy Rev. 2006, 10, 312-340. [CrossRef]

18. Lopes, A.S.; Castro, R.; Silva, C.S. Design of water pumped storage systems: A sensitivity and scenario analysis for island microgrids. Sustain. Energy Technol. Assess. 2020, 42, 100847.

19. Nikolaou, T.; Stavrakakis, G.S.; Tsamoudalis, K. Modeling and Optimal Dimensioning of a Pumped Hydro Energy Storage System for the Exploitation of the Rejected Wind Energy in the Non-Interconnected Electrical Power System of the Crete Island, Greece. Energies 2020, 13, 2705. [CrossRef]

20. Sarasúa, J.I.; Martínez-Lucas, G.; Platero, C.A.; Sánchez-Fernández, J.Á. Dual Frequency Regulation in Pumping Mode in a Wind-Hydro Isolated System. Energies 2018, 11, 2865. [CrossRef]

21. Latorre, F.J.G.; Quintana, J.J.; de la Nuez, I. Technical and economic evaluation of the integration of a wind-hydro system in El Hierro Island. Renew. Energy 2019, 134, 186-193. [CrossRef]

22. Frydrychowicz-Jastrzębska, G. El Hierro Renewable Energy Hybrid System: A Tough Compromise. Energies 2018, 11, 2812. [CrossRef]

23. Bouzounierakis, N.; Katsigiannis, Y.; Fiorentzis, K.; Karapidakis, E. Effect of Hybrid Power Station Installation in the Operation of Insular Power Systems. Inventions 2019, 4, 38. [CrossRef]

24. Katsaprakakis, D.A.; Christakis, D.G. A wind parks, pumped storage and diesel engines power system for the electric power production in Astypalaia. In Proceedings of the European Wind Energy Conference and Exhibition 2006 (EWEC 2006), Athens, Greece, 27 February-2 March 2006; pp. 621-636.

25. Edoo, N.; Ah King, R.T.F. Techno-Economic Analysis of Utility-Scale Solar Photovoltaic Plus Battery Power Plant. Energies 2021, 14, 8145. [CrossRef]

26. Serpi, A.; Porru, M.; Damiano, A. An Optimal Power and Energy Management by Hybrid Energy Storage Systems in Microgrids. Energies 2017, 10, 1909. [CrossRef]

27. Ming, M.; Wang, R.; Zha, Y.; Zhang, T. Multi-Objective Optimization of Hybrid Renewable Energy System Using an Enhanced Multi-Objective Evolutionary Algorithm. Energies 2017, 10, 674. [CrossRef]

28. Alturki, F.A.; Awwad, E.M. Sizing and Cost Minimization of Standalone Hybrid WT/PV/Biomass/Pump-Hydro Storage-Based Energy Systems. Energies 2021, 14, 489. [CrossRef]

29. Mongird, K.; Viswanathan, V.; Balducci, P.; Alam, J.; Fotedar, V.; Koritarov, V.; Hadjerioua, B. An Evaluation of Energy Storage Cost and Performance Characteristics. Energies 2020, 13, 3307. [CrossRef]

30. Nko, M.; Chowdhury, S.P.D.; Popoola, O. Application Assessment of Pumped Storage and Lithium-Ion Batteries on Electricity Supply Grid. Energies 2019, 12, 2855. [CrossRef]

31. Gamil, M.M.; Sugimura, M.; Nakadomari, A.; Senjyu, T.; Howlader, H.O.R.; Takahashi, H.; Hemeida, A.M. Optimal Sizing of a Real Remote Japanese Microgrid with Sea Water Electrolysis Plant Under Time-Based Demand Response Programs. Energies 2020, 13, 3666. [CrossRef]

32. Ferrario, A.M.; Vivas, F.J.; Manzano, F.S.; Andújar, J.M.; Bocci, E.; Martirano, L. Hydrogen vs. Battery in the Long-term Operation. A Comparative between Energy Management Strategies for Hybrid Renewable Microgrids. Electronics 2020, 9, 698. [CrossRef]

33. Dong, W.; Li, Y.; Xiang, J. Optimal Sizing of a Stand-Alone Hybrid Power System Based on Battery/Hydrogen with an Improved Ant Colony Optimization. Energies 2016, 9, 785. [CrossRef]

34. Wang, Y.; Lou, S.; Wu, Y.; Miao, M. Shaorong Wang. Operation strategy of a hybrid solar and biomass power plant in the electricity markets. Electr. Power Syst. Res. 2019, 167, 183-191. [CrossRef]

35. Selosse, S.; Garabedian, S.; Ricci, O.; Maïzi, N. The renewable energy revolution of Reunion Island. Renew. Sustain. Energy Rev. 2018, 89, 99-105. [CrossRef]

36. Selosse, S.; Ricci, O.; Garabedian, S.; Maïzi, N. Exploring sustainable energy future in Reunion Island. Util. Policy 2018, 55, 158-166. [CrossRef]

37. Stephanides, P.; Chalvatzis, K.J.; Li, X.; Lettice, F.; Guan, D.; Ioannidis, A.; Zafirakis, D.; Papapostolou, C. The social perspective on island energy transitions: Evidence from the Aegean archipelago. Appl. Energy 2019, 255, 113725. [CrossRef] 
38. Tomala, J.; Mierzejewski, M.; Urbaniec, M.; Martinez, S. Towards Sustainable Energy Development in Sub-Saharan Africa: Challenges and Opportunities. Energies 2021, 14, 6037. [CrossRef]

39. Lee, T.; Glick, M.B.; Lee, J.H. Island energy transition: Assessing Hawaii's multi-level, policy-driven approach. Renew. Sustain. Energy Rev. 2020, 118, 109500. [CrossRef]

40. Harrison, C.; Popke, J. Geographies of renewable energy transition in the Caribbean: Reshaping the island energy metabolism. Energy Res. Soc. Sci. 2018, 36, 165-174. [CrossRef]

41. Blaszke, M.; Nowak, M.; Śleszyński, P.; Mickiewicz, B. Investments in Renewable Energy Sources in the Concepts of Local Spatial Policy: The Case of Poland. Energies 2021, 14, 7902. [CrossRef]

42. Osti, G. The uncertain games of energy transition in the island of Sardinia (Italy). J. Clean. Prod. 2018, 205, 681-689. [CrossRef]

43. Mason, K.; Qadrdan, M.; Jenkins, N. Investing in generation and storage capacity in a liberalised electricity market: An agent based approach. Appl. Energy 2021, 294, 116905. [CrossRef]

44. Yapa, C.; de Alwis, C.; Ekanayake, J. Survey on blockchain for future smart grids: Technical aspects, applications, integration challenges and future research. Energy Rep. 2021, 7, 6530-6564. [CrossRef]

45. Katsaprakakis, D.A.; Christakis, D.G. The exploitation of electricity production projects from Renewable Energy Sources for the social and economic development of remote communities. The case of Greece: An example to avoid. Renew. Sustain. Energy Rev. 2016, 54, 341-349. [CrossRef]

46. Sifnos Island Cooperative. Available online: https:// sifnosislandcoop.gr/en/ (accessed on 16 November 2021).

47. Canales, F.A.; Jurasz, J.K.; Guezgouz, M.; Beluco, A. Cost-reliability analysis of hybrid pumped-battery storage for solar and wind energy integration in an island community. Sustain. Energy Technol. Assess. 2021, 44, 101062. [CrossRef]

48. Jurasz, J.; Dąbek, P.B.; Kaźmierczak, B.; Kies, A.; Wdowikowski, M. Large scale complementary solar and wind energy sources coupled with pumped-storage hydroelectricity for Lower Silesia (Poland). Energy 2018, 161, 183-192. [CrossRef]

49. Katsaprakakis, D.A.; Dakanali, I.; Condaxakis, C.; Christakis, D.G. Comparing electricity storage technologies for small insular grids. Appl. Energy 2019, 251, 113332. [CrossRef]

50. Caralis, G.; Rados, K.; Zervos, A. On the market of wind with hydro-pumped storage systems in autonomous Greek islands. Renewable and Sustainable Energy Reviews 2010, 14, 2221-2226. [CrossRef]

51. Torres-Herrera, H.J.; Lozano-Medina, A. Methodological Proposal for the Assessment Potential of Pumped Hydropower Energy Storage: Case of Gran Canaria Island. Energies 2021, 14, 3553. [CrossRef]

52. Pradhan, A.; Marence, M.; Franca, M.J. The adoption of Seawater Pump Storage Hydropower Systems increases the share of renewable energy production in Small Island Developing States. Renew. Energy 2021, 177, 448-460. [CrossRef]

53. Katsaprakakis, D.A.; Christakis, D.G.; Stefanakis, I.; Spanos, P.; Stefanakis, N. Technical details regarding the design, the construction and the operation of seawater pumped storage systems. Energy 2013, 55, 619-630. [CrossRef]

54. Hiratsuka, A.; Arai, T.; Yoshimura, T. Seawater pumped-storage power plant in Okinawa Island, Japan. Eng. Geol. 1993, 3-4, 237-246. [CrossRef]

55. Papantonis, D. Hydrodynamic Machines: Pumps and Hydro Turbines, 2nd ed.; Symeon Editions: Athens, Greece, 2016.

56. The Engineering Toolbox. Fuels Higher and Lower Calorific Values. Available online: https:/ /www.engineeringtoolbox.com/ fuels-higher-calorific-values-d_169.html (accessed on 16 November 2021).

57. European Association Battery Electric Vehicles. Energy Consumption, CO2 Emissions and Other Considerations Related to Battery Electric Vehicles. Available online: https:/ / ec.europa.eu/transport/sites/transport/files/themes/strategies/consultations/doc/ 2009_03_27_future_of_transport/20090408_eabev_\%28scientific_study\%29.pdf (accessed on 16 November 2021).

58. Chen, T.H.; Liao, R. Analysis of Charging Demand of Electric Vehicles in Residential Area. In Proceedings of the International Conference on Remote Sensing, Environment and Transportation Engineering (RSETE 2013), Nanjing, China, 26-28 July 2013. [CrossRef]

59. Denmark Technical University. European Wind Atlas. Available online: https://www.wasp.dk/wind-atlas/european-wind-atlas (accessed on 3 February 2022).

60. Burton, T.L.; Jenkins, N.; Bossanyi, E.; Sharpe, D.; Graham, M. Wind Energy Handbook, 3rd ed.; Wiley: Hoboken, NJ, USA, 2021.

61. Birdlife International. Data Zone. Greece. Available online: http://datazone.birdlife.org/site/factsheet/northern-sifnos-ibagreece (accessed on 16 November 2021).

62. Dimalexis-Bousbouras Joint Venture. Re-Evaluation Project of 69 Important Birds Areas for Their Declaration as Special Protection Areas for Birds. Composition of Action Plans for the Protection of Priority Species. Final Report. Athens, Octover 2009. Available online: https://ypen.gov.gr/wp-content/uploads/legacy/Files/Perivallon/Diaxeirisi\%20Fysikoy\%20Perivallontos/ Ektheseis\%20-\%20Meletes/20200326_programma_epanaxiologisis_69.pdf (accessed on 16 November 2021).

63. Alphan, H. Modelling potential visibility of wind turbines: A geospatial approach for planning and impact mitigation. Renew. Sustain. Energy Rev. 2021, 152, 111675. [CrossRef]

64. Rediske, G.; Burin, H.P.; Rigo, P.D.; Rosa, C.B.; Michels, L.; Siluk, J.C.M. Wind power plant site selection: A systematic review. Renew. Sustain. Energy Rev. 2021, 148, 111293. [CrossRef]

65. Katsaprakakis, D.A. Power Plant Synthesis, 1st ed.; CRC Press: Boca Raton, FL, USA, 2020.

66. Hydrogen Tools. Hydrogen Density at Different Temperatures and Pressures. Available online: https://h2tools.org/hyarc/ hydrogen-data/hydrogen-density-different-temperatures-and-pressures (accessed on 16 November 2021). 
67. Perčić, M.; Vladimir, N.; Fan, A. Life-cycle cost assessment of alternative marine fuels to reduce the carbon footprint in short-sea shipping: A case study of Croatia. Appl. Energy 2020, 279, 115848. [CrossRef]

68. Kourgialas, N.N. A critical review of water resources in Greece: The key role of agricultural adaptation to climate-water effects. Sci. Total Environ. 2021, 775, 145857. [CrossRef] [PubMed]

69. Droutsa, K.G.; Kontoyiannidis, S.; Dascalaki, E.G.; Balaras, C.A. Benchmarking Energy Use of Existing Hellenic Non-residential Buildings. Procedia Environ. Sci. 2017, 38, 713-720. [CrossRef]

70. Droutsa, K.G.; Kontoyiannidis, S.; Dascalaki, E.G.; Balaras, C.A. Mapping the energy performance of hellenic residential buildings from EPC (energy performance certificate) data. Energy 2016, 98, 284-295. [CrossRef]

71. Balaras, C.A.; Dascalaki, E.G.; Droutsa, K.G.; Kontoyiannidis, S. Empirical assessment of calculated and actual heating energy use in Hellenic residential buildings. Appl. Energy 2016, 164, 115-132. [CrossRef]

72. Księżopolski, K.; Drygas, M.; Pronińska, K.; Nurzyńska, I. The Economic Effects of New Patterns of Energy Efficiency and Heat Sources in Rural Single-Family Houses in Poland. Energies 2020, 13, 6358. [CrossRef]

73. Abdelgaied, M.; Kabeel, A.E.; Kandeal, A.W.; Abosheiasha, H.F.; Shalaby, S.M.; Hamed, M.H.; Yang, N.; Sharshir, S.W. Performance assessment of solar PV-driven hybrid HDH-RO desalination system integrated with energy recovery units and solar collectors: Theoretical approach. Energy Convers. Manag. 2021, 239, 114215. [CrossRef]

74. Okampo, E.J.; Nwulu, N. Optimisation of renewable energy powered reverse osmosis desalination systems: A state-of-the-art review. Renew. Sustain. Energy Rev. 2021, 140, 110712. [CrossRef]

75. Jelić, M.; Batić, M.; Tomašević, N. Demand-Side Flexibility Impact on Prosumer Energy System Planning. Energies 2021, 14, 7076. [CrossRef]

76. Brennenstuhl, M.; Lust, D.; Pietruschka, D.; Schneider, D. Demand Side Management Based Power-to-Heat and Power-to-Gas Optimization Strategies for PV and Wind Self-Consumption in a Residential Building Cluster. Energies 2021, 14, 6712. [CrossRef]

77. Independent Power Transmission Operator. Grid/Development: Ten-Year Network Development Plan. Available online: https:/ / www.admie.gr/en/grid/development/ten-year-development-plan (accessed on 16 November 2021).

78. Thejournal.ie: ESB Restores Power to the Aran Islands. Available online: https://www.thejournal.ie/aran-islands-power-291546 3-Aug2016/ (accessed on 16 November 2021).

79. NewEurope: Power Outage Plunges Entire Spanish Island of Menorca in Mediterranean into Darkness. Available online: https: / / www.neweurope.eu/wires/power-outage-plunges-entire-spanish-island-of-menorca-in-mediterranean-into-darkness / (accessed on 16 November 2021).

80. Law 4685/2020-OGG 92/A/7-5-2020. Update of the environmental legislation, incorporation in the Greek legislation of the European Directives 2018/844 and 2019/692 and other issues (in Greek). Available online: https://www.e-nomothesia.gr/katperiballon/nomos-4685-2020-phek-92a-7-5-2020.html (accessed on 3 March 2022).

81. Naftemporiki: On Nightmarish Levels the Electricity Selling Price in Greece. Available online: https://m.naftemporiki.gr/story/ 1814763/se-efialtika-epipeda-i-timi-tou-reumatos-stin-ellada (accessed on 18 February 2022). 